\title{
Zo gezegd, zo gedaan
}

Citation for published version (APA):

Dietz, J. L. G. (1990). Zo gezegd, zo gedaan. Academic Service. https://doi.org/10.26481/spe.19900907jd

Document status and date:

Published: 07/09/1990

DOI:

10.26481/spe.19900907jd

Document Version:

Publisher's PDF, also known as Version of record

\section{Please check the document version of this publication:}

- A submitted manuscript is the version of the article upon submission and before peer-review. There can be important differences between the submitted version and the official published version of record.

People interested in the research are advised to contact the author for the final version of the publication, or visit the DOI to the publisher's website.

- The final author version and the galley proof are versions of the publication after peer review.

- The final published version features the final layout of the paper including the volume, issue and page numbers.

Link to publication

\footnotetext{
General rights rights.

- You may freely distribute the URL identifying the publication in the public portal. please follow below link for the End User Agreement:

www.umlib.nl/taverne-license

Take down policy

If you believe that this document breaches copyright please contact us at:

repository@maastrichtuniversity.nl

providing details and we will investigate your claim.
}

Copyright and moral rights for the publications made accessible in the public portal are retained by the authors and/or other copyright owners and it is a condition of accessing publications that users recognise and abide by the legal requirements associated with these

- Users may download and print one copy of any publication from the public portal for the purpose of private study or research.

- You may not further distribute the material or use it for any profit-making activity or commercial gain

If the publication is distributed under the terms of Article $25 \mathrm{fa}$ of the Dutch Copyright Act, indicated by the "Taverne" license above, 
Zo gezegd, zo gedaan 



\section{Zo gezegd, zo gedaan}

Rede in verkorte vorm uitgesproken bij de aanvaarding van het ambt van hoogleraar in de Bestuurlijke Informatiekunde en de Bestuurlijke Informatica aan de Faculteit der Economische Wetenschappen van de Rijksuniversiteit Limburg te Maastricht op vrijdag 7 september 1990

door

dr. ir. J.L.G. Dietz 
Dietz, J.L.G.

Zo gexegd, zo gedaan / J.L.G. Diez. - Schoonhoven:

Academic Service

Oratie gehouden op 7 sept. 1990 aan de Rijksuniwersiteir

Limburg. Maastricht. - Met lit. opg.

ISBN 90-6233-622-1

SISO 803.11 UDC 007*800.1 (042.5) NUGI 852

Trefw.: communicatie / taalfilosofie / informatieanalyse.

Uitgegeven door: Academic Service

Postbus 81

$2870 \mathrm{AB}$ Schoonhowen

Zerwerk binnenwerk: Perfect Service, Schoonhoven

Omslagontwerp: Image Consult, W/assenaar

Fotografie omslag: Steven Hunt

Druk omslag: Drukkerij Veldwijk, Waddinxween

Druk binnenwerk: Krips Repro Meppel

Bindwerk: Meeuwis, Amsterdam

Copyright 1990 J.L.G. Dietz

ISBN 9062336221

NUGI 852

Niets uit deze uitgave mag worden verveelvoudigd en/of openbaar gemaakt door middel wan druk, forokopie, microfilm, geluidsband, elektronisch of op welke andere wijze ook en evenmin in een retrieval system worden opgeslagen zonder woorafgaande schriftelijke toestemming van de uitgever. 


\section{Inhoud}

1 Informatiekunde en informatica 7

2 Probleemstelling en inleiding 13

3 Communicatie in organisaties 19

4 Het conceptuele procesmodel 31

5 Het conceptuele informatiemodel 44

6 Informatiekundig onderwijs en onderzoek 55

$\begin{array}{ll}\text { Dankbetuiging } & 61\end{array}$

$\begin{array}{ll}\text { Literatuurlijst } & 63\end{array}$ 
: 


\section{Informatiekunde en informatica}

De toehoorders van een inaugurele oratie mogen verwachten dat de inhoud ervan betrekking heeft op het vakgebied waarin de orator is benoemd. Aan die verwachting wil ik gaarne voldoen, maar hoe, zo vroeg ik mij bij het opstellen van deze rede af, kunnen mijn toehoorders weten wat bestuurlijke informatiekunde en bestuurlijke informatica is? Ik heb toen voor de aardigheid eens de 'dikke van Dale' geraadpleegd [van Dale, 1985]. Het woord 'informatiekunde' komt er niet in voor, noch de combinatie van het adjectief 'bestuurlijk' met 'informatiekunde' of 'informatica'. Alleen 'informatica' is er in opgenomen, en wel met de volgende betekenissen:

1. leer van de mechanische verwerking van informatie, informatiemathematica;

2. vrouwelijke informaticus.

Betekenis 1 is zeker niet onjuist, maar anno 1990 toch wel erg beperkt: te veel belangrijke deelgebieden van de informatica worden door deze definitie nauwelijks gedekt. Betekenis 2 is perfect, maar daar ga ik het niet over hebben.

Wat ik wel ga ondernemen is een poging het begrip van informatica c.q. informatiekunde te verdiepen door enkele fundamentele onderwerpen op een niet al te lastige maar wel indringende wijze met $u$ te bespreken. Als aftrap geef ik een antwoord op vijf veel gestelde vragen.

Vraag: is informatiekunde hetzelfde als informatica? Antwoord: nee, maar men kan ook zeggen: ja. 
De discussie over afbakening en naamgeving van informatica en informatiekunde en van de diverse deelgebieden binnen beide is gelukkig geluwd. Hoewel ik me er ook zelf kort in heb gemengd, acht ik het thans een zinloze bezigheid. Die discussie is vooral een formidabele uiting van Hollandse keuteligheid, die buiten onze grenzen nauwelijks wordt begrepen. Het ligt voor de hand 'informatica' als de meest omvattende naam te gebruiken, omdat deze naam in de maatschappij al ongeveer zo'n brede betekenis heeft en omdat er een goede vertaling in andere talen voorhanden is. Overigens zou in het Engels de vertaling niet 'computer science' maar 'informatics' zijn.

Informatiekunde beschouw ik dan als een specialisatie binnen informatica. Geprojecteerd op de ontwikkelingscyclus van een informatiesysteem betreft deze specialisatie in hoofdzaak alle werkzaamheden die voorafgaan aan, en beogen te leiden tot, het vaststellen van de specificaties van een informatiesysteem.

Vraag: is er maar één informatiekunde?

Antwoord: ja, er is maar één informatiekunde, maar er zijn vele verschijningsvormen.

Er zijn inderdaad nogal wat verschijningsvormen van informatiekunde en het aantal lijkt nog dagelijks toe te nemen. Heel bekende zijn bestuurlijke informatiekunde en medische informatiekunde. De laatste wordt overigens meestal medische informatica genoemd, een aanwijzing voor de onduidelijkheid van het onderscheid tussen informatica en informatiekunde. Evenzo wordt bestuurlijke informatiekunde wel bedrijfsinformatica genoemd.

Het is mijns inziens niet gewenst de aanduiding van het toepassingsgebied te benadrukken. Wat de verschillende verschijningsvormen bindt, is belangrijker dan wat hen 
scheidt. In het navolgende zal ik daarom steeds van informatiekunde spreken en heb ik als toepassingsgebied het functioneren van organisaties voor ogen; met andere woorden, het gaat over bestuurlijke informatiekunde. Voor het gemak reken ik daaronder ook bestuurlijke informatica. In dit deelgebied ligt het accent op het implementeren van wiskundige oplossingen van beslissingsproblemen met gebruikmaking van informatietechnologie.

Vraag: beeft informatiekunde met computers te maken? Antwoord: ja, maar de centrale thema's binnen de informatiekunde hebben niets met computers te maken.

Een essentieel kenmerk van informatiekunde is dat het een ontwerp- ofwel ingenieursdiscipline is. Het gaat er steeds om oplossingen voor problemen, algemeen gezegd: informatiesystemen, te ontwerpen, waarbij optimaal gebruik wordt gemaakt van de mogelijkheden die de moderne informatietechnologie biedt (computers, netwerken, databases etc.). Tot de centrale thema's behoren dan ook systeemanalyse, informatie-analyse, modelleren en specificeren. 'Centraal' betekent overigens niet 'het meest besproken' of 'actueel'. Indien men zulke criteria aanlegt, zouden onderwerpen als informatiemanagement en projectmanagement tot de kern van het vakgebied behoren, en dat is mijns inziens niet het geval. Beide onderwerpen zijn primair managementaangelegenheden. Elke goede manager is in staat de functie van informatiemanager of projectmanager te vervullen. Onder een goede manager versta ik iemand die adviezen inwint van terzake deskundigen - omdat hij weet dat hij zelf geen deskundige is - en die zonder dralen beslissingen neemt. Voor alle duidelijkheid: ik zeg niet dat deze onderwerpen niet in een informatiekundig curriculum thuishoren, dat doen ze zéker wel; ik zeg alleen dat ze geen kernvakken zijn. 
Vraag: beeft informatiekunde iets met organisatiekunde te maken?

Antwoord: wis en waarachtig!

Organiseren en informatiseren zijn elkaar aanvullende en, tot op zekere hoogte, uitwisselbare oplossingswijzen van het coördinatieprobleem van een organisatie. Het coördinatieprobleem is het primaire probleem van elke organisatie. Simpel gezegd is dat probleem de noodzaak voor de personen in een organisatie om voortdurend af te stemmen wat ze gedaan hebben en te overleggen wat ze zullen doen, teneinde ervoor te zorgen dat het gezamenlijke doel wordt bereikt. Dat geldt gelijkelijk voor strategische, voor tactische en voor operationele aangelegenheden.

De organisatiekundige oplossing bestaat uit het verminderen van de noodzaak tot overleg. Voorbeelden van maatregelen die daartoe strekken, zijn specialiseren, standaardiseren en het aanbrengen van hiërarchie. De mate waarin de organisatiekundige oplossing wordt toegepast, heet de organiseringsgraad. Hoe hoger de organiseringsgraad van een organisatie, des te lager de noodzaak voor overleg en dus voor communicatie, maar ook des te moeilijker het wordt zich aan te passen aan veranderende omstandigheden.

De informatiekundige oplossing bestaat uit het vergroten van het overlegvermogen van de personen in de organisatie door ondersteuning van de communicatie en de besluitvorming met behulp van geschikte systemen. Het toepassen van de informatiekundige oplossing is mogelijk geworden door de moderne informatietechnologie. De mate waarin van de informatiekundige oplossing gebruik wordt gemaakt, noem ik de informatiseringsgraad van een organisatie. De voordelen van een hoge informatiseringsgraad zijn evident, maar er zijn ook nadelen, zoals de kosten van het ontwikkelen en beheren 
van geautomatiseerde informatiesystemen en de afhankelijkheid van een nu eenmaal niet perfecte technologie.

Het is overigens niet zo dat organisaties veel vrijheid hebben in her bepalen van de organiseringsgraad en de informatiseringsgraad. Voor beide geldt feitelijk een bepaald minimum, dat sterk afhankelijk is van de bedrijfskarakteristieken. Zoals Mulder in zijn oratie al memoreerde [Mulder, 1990], is de verwachting van organisatiekundigen dat de hiërarchische organisatie plaats gaat maken voor de professionele; anders gezegd, dat er een tendens is de organiseringsgraad te verlagen. Ten gevolge van deze ontwikkeling wordt het belang van een goed functionerende informatievoorziening dus groter.

\section{Vraag: is informatiekunde moeilijk?}

Antwoord: nee, maar bet kan wel moeilijk worden gemaakt.

Informatiekunde is eerst en vooral de kunde om op een kritische wijze het fenomeen informatie tegemoet te treden, om de onzin, dat wil zeggen de onduidelijkheden, de dubbelzinnigheden en de tegenstrijdigheden in aangeboden informatie, te ontdekken en om deze fouten te vermijden in de informatie die men zelf produceert. I $\mathrm{k}$ ben me ervan bewust, dat dit voor velen geen zaak is van informatiekunde, maar veeleer van algemeen logisch en kritisch denken. Ik bestrijd dat ook niet, maar vind het anderzijds zo wezenlijk noodzakelijk voor iedereen die omgaat met geautomatiseerde informatiesystemen (en hoevelen zijn dat er al niet?), dat ik het er maar liever wel toe reken. De reden voor deze aandacht wordt treffend geillustreerd door de afbeelding op de omslag van dit boekje. In plaats van direct van mens tot mens te communiceren in een natuurlijke taal, zal men dat in de toekomst steeds vaker via artefacten, computers geheten, doen in tamelijk geformaliseerde subsets van zo'n taal. Daarmee vervalt een 
niet te onderschatten element in het begrijpen door mensen van elkaars boodschappen. Als mensen niet worden voorbereid op dir zogeheten informatietijdperk, kunnen er gemakkelijk situaties ontstaan, in vergelijking waarmee de Babylonische spraakverwarring nog maar kinderspel is. Het onderwijzen van deze, laat ik het maar noemen basisinformatiekunde, acht ik daarom wan groot maatschappelijk belang en niet voorbehouden aan het hoger onderwijs alleen. Deze basisinformatiekunde zou tot het verplichte vakkenpakket van het Avo en het vwo dienen te behoren!

Ook informatiekunde in engere zin, waarmee ik het vak bedoel dat men beroepsmatig kan uitoefenen, is niet intrinsiek moeilijk, maar het kan wel moeilijk worden gemaakt. Zoals iemand die alleen de programmeertaal Basrc kent, grote moeite heeft om te begrijpen wat de essentie van programmeren is, zo zal iemand die geen andere modelleringstechnieken kent dan bijvoorbeeld Entiteit Relatie Diagrammen [Chen, 1976] en Data Flow Diagrammen [Ward en Mellor, 1985], zich nier gemakkelijk een juist inzicht in de informatiekunde verwerven. Het probleem daarbij is niet eens zozeer de technieken zelf, maar vooral de achterliggende denkwerelden. De meeste thans beschikbare theorieën, methoden en technieken zijn niet alleen ontoereikend voor de problemen die zich aandienen, maar blokkeren ook degenen die er mee werken in her vinden van nieuwe en betere denk-en werkwijzen. lets afteren blijkt vaak veel lastiger dan iets aanleren.

De vooruitgang van de informatiekunde wordt vooral gehinderd door een rekorr aan goede theoretische fundamenten en door een teveel aan beoefenaren en leermeesters, die dat niet zo erg lijken te vinden. 


\section{Probleemstelling en inleiding}

Laat ik dan nu een aanvang maken met het uitdiepen van een misschien niet zo actueel, maar wel heel essentieel probleem in de informatiekunde. Om u als toehoorder nauw daarbij te betrekken heb ik mijn betoog gegoten in een vorm die is ontleend aan Nielen's boekje, getireld 'De bedoeling van informatie voor mens en organisatie' [Nielen, 1976], dat ik overigens nog steeds als de beste introductie beschouw in de informatiekunde. De gedeelten van thet betoog waarin ik me, zoals tot hiertoe is gebeurd, op de gebruikelijke, nogal afstandelijke, wijze tot $\mathrm{u}$ richt, worden afgewisseld door passages waarin ik u meer persoonlijk lijk te betrekken door ú te laten spreken, maar in werkelijkheid via $u$ weer mijzelf aan het woord laat. Hieronder volgt de eerste passage van dit soort.

$U$ bent geïnteresseerd in systeernkunde, zowel de harde als de zachte, in tal en logica, en in ontologie. Wat de systeemkunde betreft hebt $u$ onder andere Beer [Beer, 1966], Weinberg [Weinberg, 1975], Checkland [Checkland, 1981] en in 't Veld [in 't Veld, 1988 J gelezen en om uw gevoel voor de betrekkelijkheid van het systeemdenken op peil te bouden bebt $u$ zich kostelijk geamuseerd met het boekje 'Systemantics' van Gall [Gall, 1979]. Wat taal en logica betreft hebt u enkele inleidende boeken bestudeerd, bebt $u$ een serieuze poging ondernomen Wittgenstein [Wittgenstein, 1982] te doorgronden en bent u geboeid geraakt door het boek 'Conceptual Structures' wan Sowa [Sowa, 1984]. Verder beeft het lezen van 'Understanding Computers and Cognition' door Winograd en Flores 
[Winagrad en Flores, 1986$]$ u geinspireerd tot nieuwe gedachten en hebt u zich door middel wan Searle [Searle, 1969 en 1979] verdiept in de taalfilosofie. Wat de ontologie betreft hebt $u$ enkele tegenvallers achter de rug en bent $u$ nu min of meer verknocht geraakt aan Bunge [Bunge, 1979].

Naast de dingen die u gedaan bebt, zijn minstens zo belangrijk de dingen die $u$ nagelaten hebt te doen. Het strekt bijvoorbeeld tot un voordeel dat u geen van de bestadnde cursorische opleidingen in de informatiekunde bebt genoten. In het bijzonder bent un niet gehersenspoeld door een van de zeer vele methoden, zoals daar zijn: AXIAL, $B S P, D 2 S 2, E R M, H O S, I D A, I E M$, INFOMOD, ISAC, JSD, MERISE, Method/1, NLAM, PSL/PSA, SADT, SASO, SDM, SSADM, STRADIS, uSE en Yourdon's SA.

Ter illustratie zal ik de gedachten die in de volgende hoofdstukkken worden ontwikkeld, steeds toepassen op een fictieve voorbeeldsituatie. Daarvoor heb ik het Maastrichtse bedrijf 'Bak \& Eet' gekozen. Achter deze naam gaat een florerend bakkersbedrijf schuil, dat niet alleen zoete koekjes, maar ook stevige maagvullingen produceert. De directeur van Bak $\&$ Eet is nogal gesteld op cultuur. Deze voorliefde brengt hij soms tot uitdrukking in de namen van de produkten. Om een indruk te geven van de geproduceerde artikelen is in figuur 1 een overzicht van het assortiment opgenomen.

\begin{tabular}{|c|c|c|c|}
\hline artikel & artikelsoort & smaak & prijs \\
\hline Histoire d'O. & taant & zoet & $f 12,00$ \\
\hline Megatrends & whai & zoet & $f 10,00$ \\
\hline Christiane $\mathrm{E}$ & koek & hartig & $f \quad 8,50$ \\
\hline Bosbessencaart & taart & hartig & $f 11,50$ \\
\hline Bramenvlaai & soess & romig & f 1,75 \\
\hline Innocentia & talart & kruidig & dagprijs \\
\hline
\end{tabular}

Figuar 1 
Dat Bramenviaai een soes is vindt u wel geestig. Voor u was het immers al langer gesneden koek dat in de informatiekunde een naam niet meer dan een etiket is en dus geen enkele informatie over de eigenschappen van het benoemde object bevat. Natuurlijk, er bestaan ook classificerende codes, maar de voordelen daarvan blijken toch steeds weer niet op te wegen tegen de nadelen, dus blijf als essentielle functie van een naam het identificeren van een abject over. Daarmee is tevens verklaard dat de Basbessentaart bartig kan zijn.

De organisatie van Bak \& Eet is vrij traditioneel: zo is er een winkel, een bakkerij, een afdeling Inkoop, een afdeling Informatie \& Statistiek en een afdeling Verkoop. De laatste stelt de verkoopplannen op, die als uitgangspunt dienen voor de door het hoofd van de bakkerij te maken produktieplannen. De directeur stelt zelf de prijzen vast. Daarvoor raadpleegt hij de afdeling Verkoop, die de marktprijzen in de gaten houdt, en de afdeling Informatie \& Statistiek, die de kostprijzen berekent. Hoewel voor een belangrijk deel de taakstellingen en werkwijzen schriftelijk zijn vastgelegd, is het bedrijf ook rijk aan wat men tegenwoordig expertkennis noemt. Een voorbeeld van zulke (heuristische) kennis, aanwezig bij ervaren bakkers, is dat je de Histoire d'O. en de Christiane F. beter niet tegelijk in de oven kunt doen, ze branden dan allebei gemakkelijk aan. Op het modelleren van deze soort van kennis ga ik hier overigens niet in.

$U$ bent door Bak of Eet gevraagd een voorstel te doen tot bet verbeteren van de informatievoorziening, en $u$ wilt dat nu eens serieus en professioneel aanpakken. Wat u niet wilt, is het uitvoeren van bijvoorbeeld een Activiteitenstudie volgens ISAC [Lundeberg, 1979]. Zoiets bebt u nu vaak genoeg gedaan of zien doen om zeker te weten dat er meer 
wit een dergelijke analyse te balen is. Ook hebt u ervaren dat de bestadide methoden niet noodzakelijkerwijs to bet beste veranderingsvoorstel leiden en, misschien nog erger. dat je ook niet weet hoever je daar wan af zit.

Het probleem dat in de volgende drie hoofdstukken wordt besproken, is het modelleren van een (deel van een) organisatie zodanig dat het resultaat een geschikte basis vormt voor het (her)ontwerp van de informatievoorziening van de organisatie. De personen die deel uitmaken van een organisatie, worden actoren genoemd. Met actor bedoel ik vervolgens niet zozeer een persoon als wel een organisatorische functie. Zo'n functie kan in principe door een aantal personen worden vervuld en een persoon kan bij de vervulling van een aantal functies zijn betrokken. Actoren voeren taken uit en communiceren met elkaar en met (actoren in) de omgeving.

De handelende en communicerende actoren vormen tezamen een systeem. Omdat de actoren de subjecten zijn van dat handelen en communiceren, noem ik zo'n systeem een subjectsysteem. Het subjectsysteem van Bak \& Eet omvat onder andere de actor ' $k$ lanten' en de actor 'winkel', en her kopen van artikelen door klanten in de winkel.

Een model van het handelen en communiceren der actoren heet een procesmodel. Een procesmodel waarbij volledig is geabstraheerd van de wijze waarop het proces is gerealiseerd, noem ik een conceptueel procesmodel.

De dingen ofwel entiteiten waarop het communiceren van actoren betrekking heeft, vormen ook een systeem. Omdat deze dingen de voorwerpen van het communiceren zijn, noem ik zo'n systeem een objectsysteem. Het objectsysteem van Bak \& Eet omvat onder andere de artikelen en hun kenmerken zoals de smaak en de prijs.

Een model van de entiteiten en hun kenmerken wordt een conceptueel informatiemodel genoemd. De achtergrond voor 
deze benaming is, dat men het ook kan opvatten als een beschrijving van de betekenis van de informatie die de actoren ontvangen en produceren. De toevoeging conceptueel duidt erop dat men volledig abstraheert van de wijze waarop die informatie wordt vastgelegd.

Bij een subjectsysteem hoort altijd een bepaald objectsysteem, en omgekeerd. Actoren en hun handelingen kunnen zowel tot het subjectsysteem als tot het objectsysteem van een organisatie behoren. In Bak \& Eet bijwoorbeeld zal dat het geval zijn voor de klanten en voor de bestellingen die klanten plaatsen.

Het maken van informatiemodellen is, althans in theorie, een begrepen zaak. Aan deze klasse van modellen zal ik dan ook de minste aandacht schenken. Een kernpunt in de theorie van informatiemodellen is de onderscheiding van drie niveaus van abstractie, te weten het conceptuele niveau, het logische niveau en het fysische niveau.

Op het conceptuele niveau worden de relevante semantische eenheden van informatie vastgesteld. Een semantische eenheid is een eenheid van betekenis. De zin 'De Megatrends is een vlaai en kost $f 10,-'$ bijvoorbeeld bestaat uit twee semantische eenheden, namelijk 'De Megatrends is een vlaai' en 'De Megatrends kost $f 10,-'$. Een informatiemodel op het conceptuele niveau abstraheert volledig van de wijze waarop informatie uiteindelijk door middel van media (papier, magnetiseerbare materialen, halfgeleiders etc.) wordt opgeslagen. Dat laatste is juist een zaak voor het fysische niveau. Het logische niveau neemt een middenpositie in. Op dit niveau worden de syntactische eenheden van informatie vastgesteld; dat zijn de eenheden van opslag en transport. Een syntactische eenheid omvat een aantal semantische eenheden. De syntactische eenheid van de informatie in figuur 1 bijvoorbeeld is de 
tabelregel. Deze omvat drie semantische eenheden namelijk $^{2}$ het artikelsoort, de smaak en de prijs van een artikel.

Bij een bepaald objectsysteem hoort precies één conceptueel informatiemodel, terwijl er op het logische en het fysische niveau een keuze gemaakt kan worden uit verschillende kandidaatmodellen.

Aan de kant van de procesmodellen is het onderzoek nog niet zover gevorderd. Met name ontbreekt eigenlijk de tegenhanger van het conceptuele informatiemodel, het conceptuele procesmodel dus. Aan deze klasse van modellen zal ik daarom de meeste aandacht besteden. Er is wel sprake van tegenhangers op het logische en het fysische niveau. Op het logische niveau zijn dat bijvoorbeeld het Data Flow Diagram [Ward en Mellor, 1985] en het A-schema [Lundeberg, 1979], hoewel voor beide modelsoorten geldt dat ze lang niet zo precies zijn gedefinieerd als bijvoorbeeld het Relationele Model [Date, 1986] aan de kant van de informatiemodellen. Op het fysische niveau tenslotte bevinden zich de modelsoorten waarin de ard van de informatiedrager een rol speelt. De toepassing van deze modelsoorten treft men vooral aan in de praktijk van de Administratieve Organisatie.

Een gemeenschappelijke basis voor conceptuele informatiemodellen en concepruele procesmodellen kan worden gevonden in de taalfilosofische analyse van communicatie. Deze theorie, alsmede een praktische uitwerking ervan, wordt besproken in hoofdstuk 3. In hoofdstuk 4 komt dan het conceptuele procesmodel aan de orde en in hoofdstuk 5 het conceptuele informatiemodel. 


\section{Communicatie in organisaties}

Onder communicatie versta ik hier menselijke communicatie, dat wil dus zeggen de overdracht wan berichten waardoor de ene menselijke geest de toestand van een andere menselijke geest beïnvloedt. De aandacht is daarbij gericht op de inhoud, de bedoeling en het effect van communicatie. Afgezet tegen de indeling die in de semiotiek wordt gehanteerd (zie bijvoorbeeld [van Peursen, Bertels en Nauta, 1968]), is het blikveld beperkt tot het pragmatische en het semantische aspect van informatie. De klassieke communicatietheorie van Shannon [Shannon, 1948] valt hier dus geheel en al buiten. Vervolgens beperk ik me tot berichten die als zinnen in een natuurlijke taal, laat ik voor het gemak zeggen: in het Nederlands, worden uirgedrukt. Het theoretische fundament voor de analyse van zulke communicatie is gelegen in de 'Speech act theory'. De pionier van deze theorie is de filosoof Austin [Austin, 1962], terwijl Searle, een leerling van hem, voor uitbouw en verfijning heeft gezorgd [Searle, 1969; Searle, 1979]. De vertaling van 'speech act' is taalhandeling. Men kan dus zeggen dat mensen door te spreken (of te schrijven) en te luisteren (of te lezen) talalhandelingen verrichten. De beperking van de te bestuderen communicatie tot datgene wat in Nederlandse zinnen kan worden uitgedrukt, lijkt misschien ernstig, maar is dat geenszins. Volgens het 'principle of expressibility' van Searle kan namelijk elke (andere) vorm van communicatie ook in natuurlijke taal worden uitgedrukt. Daaronder vallen bijvoorbeeld ook lichaamstaal en kunstuitingen. Voor de discussie hier is het voldoende 
naast het gesproken en geschreven woord aan schema's, diagrammen en tabellen te denken.

De filosoof Habermas heeft de theorie van Austin en Searle in een breder kader geplaatst en er de naam 'communicatief handelen" aan gegeven, met het doel het talig handelen dat door de 'Speech act theory' wordt verklaard, te onderscheiden van andere soorten talig handelen zoals het strategische handelen [Koningsveld en Mertens, 1986]. Tot het communicatieve handelen wordt alle communicatie gerekend waarbij de zender van een bericht geen bijbedoelingen heeft naast de letterlijke, objectieve, bedoeling van het gesproken of geschreven bericht. Er zijn meer voorwaarden waaraan het communicatieve handelen in de theorie van Habermas is gebonden, maar daar ga ik hier niet op in. In het navolgende wordt met de term 'taalhandeling' steeds een communicatieve taalhandeling bedoeld.

Bij het uitvoeren van een taalhandeling zijn er drie componenten in het spel: de zender, de ontvanger, en het bericht. In plaats van bericht gebruikt men in de taalkunde meestal het woord 'zin'. Een zin is zelf weer een samenstelling van twee componenten, de illocutie en de propositie geheten.

De begrippen illocutie en propositie worden uitgelegd aan de hand van de volgende vier zinnen.

1. 'Zou je een Bramenvlaai willen bezorgen bij professor Beek?'

2. 'Ik zal een Bramenvlaai bezorgen bij professor Beek.'

3. 'Er is een Bramenvlaai bezorgd bij professor Beek.'

4. 'Is er een Bramenvlaai bezorgd bij professor Beek?'

Deze zinnen bevatten allemaal dezelfde propositie, namelijk "Er is een Bramenvlaai bezorgd bij professor Beek'. De propositie van een zin is een uitspraak die waar of onwaar is met 
betrekking tot een bepaald referentiedomein, dat ik in hoofdstuk 2 het objectsysteem heb genoemd, maar dat in de informatiekunde gewoonlijk de 'Universe of Discourse' heet. In dit geval is het objectsysteem er een, waarin 'Bramenvlaaien' en 'professoren' als entiteiten, en 'bezorgen' als activiteit een rol spelen.

De Nederlandse uitdrukking 'Universum van Discussie', die als vertaling van 'Universe of Discourse' in zwang dreigt te geraken, vindt u verwerpelijk. $U$ bad al moeite met het woord 'Universe', omdat u dat had gereserveerd voor het enige altijd gesloten systeem, waarvan elk systeem een subsysteem is en elk ding een component. De vertaling van 'Discourse' door discussie doet voor $u$ definitief de deur dicht. U besluit voortalan het woord 'objectsysteern' of bet woord 'wereld' te gebruiken, of desnoods de term onvertaculd te laten.

Voor het gemak nemen we aan dat de propositie van een zin steeds een elementaire propositie is. Dat is een propositie die uit één werkwoordelijk deel en een aantal naamwoordelijke delen is opgebouwd. De propositie in de voorbeeldzinnen is een elementaire propositie, waarvan het werkwoordelijke deel de term 'is bezorgd bij' is. Er zijn twee naamwoordelijke delen: 'professor Beek' en 'een Bramenvlaai'.

De illocutie van een zin drukt de bedoeling van de zender en het effect op de ontvanger uit. In elk van de vier voorbeeldzinnen is de illocutie verschillend van die in de andere.

De eerste zin is een verzoek. De essentie van een verzoek is dat de zender probeert de ontvanger tot zodanig handelen aan te zetten, dat de propositie van de zin waar wordt. Voor het slagen van een verzoek moet aan twee voorwaarden zijn voldaan: de zender dient het verzoek oprecht te bedoelen en 
de zender moet weten dat de ontvanger in staat is aan het verzoek te voldoen.

De tweede zin is een belofte. Van een belofte is de essentie dat de zender zich verplicht tegenover de ontvanger zodanig te handelen, dat de propositie waar wordt. De voorwaarde voor het slagen van een belofte is dat de zender de belofte oprecht meent.

De derde zin is een bewering. De essentie van een bewering is dat de zender gehouden is aan de waarheid van de propositie; met andere woorden, de ontvanger kan erop vertrouwen dat de propositie inderdaad waar is. De zender moet in staat zijn zonodig het bewijs ervan te leveren.

De vierde zin tenslotte is een vraag. De essentie daarvan is dat de zender probeert van de ontvanger uitsluitsel te verkrijgen omtrent de waarheid van de propositie.

Om de illocutie en de propositie van zinnen duidelijk te laten uitkomen kan een zin worden herschreven in een gestandaardiseerde notatie waarin beide een eigen syntactische vorm hebben, gescheiden door een dubbele punt. De gegeven voorbeeldzinnen zien er dan als volgt uit:

1. 'Ik verzoek je: er is een Bramenvlaai bezorgd bij professor Beek.'

2. 'Ik beloof je: er is een Bramenvlaai bezorgd bij professor Beek.'

3. 'Ik zeg je: er is een Bramenvlaai bezorgd bij professor Beek."

4. 'Ik vraag je: er is een Bramenvlaai bezorgd bij professor Beek.'

De gelijkheid van propositie van de vier zinnen blijkt in de gestandaardiseerde notatie direct en duidelijk. Het is belangrijk in te zien dat de aspecten propositie en illocutie weliswaar kunnen worden ónderscheiden, maar niet kunnen worden 
géscheiden: elke zin heeft onlosmakelijk een propositie én een illocutie. Het behoeft geen betoog dat men buj de analyse van informatie rekening dient te houden met deze onderscheiding.

Bij het overdenken van de consequenties wan de lantste zin merkt w op, dat bet onderscheid tussen illocutie en propositie in de buidige informatiekundige methoden voor bet modelleren van informatie niet wordt gemaakt. U stelt allereerst vast dat de meeste methoden niet eens de link net communicatie in de natumlijke taal leggen en zich eigenlijk alleen richten op bet ontwerpen van gegevensstructuren ten behoeve wan computerverwerking. Van de paar methoden die wel op de structuren van de natuurlijke taal zijn gebaseerd, zoals NIAM [Nijssen, 1989] en INFOMOD IVan Grietbuysen en Jardine, 1989], stelt u vervolgens vast dat bet daarin alleen gaat om de structuur wan proposities en dat de bewering meestal stilzwijgend als illocutie wordt verondersteld.

Naast het verzoek, de belofte, de bewering en de vraag worden er in de 'speech act theory' nog diverse andere illocuties onderscheiden. Sommige daarvan zijn voor ons doel niet zo interessant. Dat geldt bijvoorbeeld voor een zin als 'Ik vind het erg fijn voor professor Beek, dat hij een Bramenvlaai krijgt". Deze zin drukt een gemoedstoestand uit. Wel interessant, zelfs zeer interessant, is de illocutie in de volgende zinnen.

5 a 'De prijs van de Innocentia is vandaag $f 2,30$.'

$5 b$ "Ik benoem u tot gouverneur van Limburg."

5c 'De Bramenvlaai gaat uit het assortiment.' 
Al deze zinnen hebben de illocutie verklaring. Een verklaring heeft veel weg van een bewering; voor beide illocuties geldt namelijk dat de zender gehouden is aan de warheid van de propositie. Het verschil zit hem in de wijze waarop de zender die waarheid kan aantonen. Bij een bewering gebeurt dat door het observeren van de toestand waarnaar de propositie verwijst, terwijl een verklaring die toestand zelf creëert. Een voorwaarde daarbij is wel dat de zender de bevoegdheid heeft tot het uitspreken van de verklaring. Niet iedereen die de zin 'Ik benoem u rot gouverneur van Limburg' uitspreekt, heefr daarmee een gouverneur benoemd, ook al zou men dat nog zo graag willen. Verklaringen illustreren bij uitstek dat de toestand van de wereld in hoge mate door taalhandelingen wordt gemaakt [Austin, 1962]. Searle gaat op deze bijzondere eigenschap van taal uitgebreid in, waarbij hij een onderscheid maakt tussen 'brute facts' en 'institutional facts' [Searle, 1969]. 'Brute facts' zijn proposities die in principe voor iedereen waarneembare zaken betreffen, en die dus door beweringen kunnen worden medegedeeld. De propositie in de zinnen 1 tot en met 4 is een typisch voorbeeld van een 'brute fact'. 'Institutional facts' zijn proposities die als referentiedomein een maatschappelijke institurie hebben. De propositie in zin 5b is een typisch voorbeeld van een 'institutional fact'. Instituties zijn menselijke creaties, bestaande uit een verzameling wetten en regels. 'Institutional facts' hebben daarom alleen maar betekenis voor degene die op de hoogte is van deze wetten en regels. Voor iemand die de betreffende werten en regels niet kent, is het bijwonen van een huwelijkssluiting op zijn best een amusante aangelegenheid. Evenzo zal het vlaggen door de grensrechter en het opsteken van een hand door de scheidsrechter gemakkelijk vreemde gedachten kunnen opwekken bij iemand die de regels van het voetbalspel niet kent. 
Een organisatie die een implementatie of belichaming is van een institutie, noem ik een institutionele organisatie. Bekende voorbeelden van zullke organisaties zijn banken, verzekeringsmaatschappijen en pensioenfondsen.

Deze gedachten luchten $u$ op. U hebt altijd al een ongemakkelijk gevoel gehad bij de heersende opvatting dat institutionele organisaties primair gegevensverwerkende organisaties zijn, en bijvoorbeeld een koekfabriek of een autoverbuturbedrif niet. Het probleem dat informatiekundigen hebben met institutionele organisaties, is natuurlijk dat er geen fysiek primair proces is aan te wijzen. Daarom is het niet mogelijk de bekende analysepatronen, zoals het PBI-model van Bemelmans [Bemelmans, 1986] of het informatieparadigma van Brussaard en Tas [Brussaard en Tats, 1980J toe te passen. Het wordt u nu duidelijk dat het primaire proces wan dit soort organisaties bestaat uit taalhandelingen en dat het resultaat daaruan is het aangaan van verplichtingen (Engels: commitments). De verschillen tussen de gegevensverwerking in een verzekeringsmaatschappij en die in een koekfabriek vindt u vervolgens niet principieel maar gradueel: alleen de relarieve omvang van de informatiehuishouding c.q. de administratie is verschillend. Nadenkend over die relatief grote omvang van de administratieve functie in institutionele organisaties dringen zich associaties met waterhoofden en woekerende gezwellen aan u op. Het lukt u gelukkig deze ongepaste gedachten snel te onderdrukken, maar de overtuiging dat er door automatisering een grote verbetering van de doelmatigheid verkregen zou kunnen worden , blijft lewend. 
De illocutie-indeling van Searle vervang ik nu door een indeling waarin nog maar twee soorten illocuties worden onderscheiden, directief en constatief geheten.

Een zin met de illocutie directief is een combinatie van een verzoek en de belofte om aan het verzoek gevolg te geven. Door middel van een directieve zin geeft de zender dus opdracht aan de ontvanger tot toekomstig handelen. De rechtvaardiging van deze combinatie is dat in organisaties bij afspraak de ontvanger van een verzoek de behandeling ervan niet kan weigeren. Dit betekent niet dat het verzoek altijd zal worden gehonoreerd, maar wel dat dit wordt geprobeerd. Als bijvoorbeeld iemand een Bramenvlaail bestelt en die blijkt uitverkocht te zijn, hoeft de verkoper dat verzoek niet te honoreren, terwijl hij toch niet van plichtsverzuim kan worden bericht.

Een zin mer de illocutie constatief is een combinatie van een bewering of een verklaring en de vraag naar het beweerde of verklaarde. Door middel van een constatieve zin doet de zender mededeling van een toestandsverandering ten behoeve van de ontvanger. Deze combinatie is een essentiële in het licht van de probleemstelling die in hoofdstuk 2 is geschetst. De overweging bij het uitsluiten van de vraag als afzonderlijke illocutie is de volgende. Als een actor iets mag of moet weten, is her voldoende dat wast te leggen als een recht op informatie van de actor. De wijze waarop de actor vervolgens van zulk recht gebruik maakt of kan maken, is een kwestie van implementatie. Dit abstraheren van implementatie illustreert het conceptuele karakter van het in hoofdstuk 4 behandelde, op de onderscheiding van directieve en constatieve zinnen gebaseerde, procesmodel.

Aan elke zin voeg ik vervolgens een geldigheidsperiode toe. Voor een constatieve zin is de betekenis daarvan dat alleen gedurende deze periode de propositie waar is. Voor een directieve zin is de betekenis dat de gevraagde handelingen binnen 
die periode moeten worden verricht. De combinatie van een zin, die dus bestaat uit een illocutie en een propositie, en een geldigheidsperiode noem ik een feit. Een feit met de illocutie directief heet een directief feit of kortweg een directief. Een feit met de illocutie constatief heet een constatief feit of kortweg een constatief.

Het essentiële onderscheid tussen directieven en constatieven is het tegengesteld zijn van de eigenschap 'direction of fit zoals Searle die noemt [Searle, 1979]. Her begrip 'fit' heeft betrekking op het met elkaar in overeenstemming brengen van de propositie van een taalhandeling (ofwel: het woord) en de werkelijkheid (ofwel: de wereld). Er zijn twee mogelijke 'directions of fit': men brengt het woord in overeenstemming met de wereld of men brengt de wereld in overeenstemming met het woord. Bij een constatief hoort de eerste richting, bij een directief de tweede. Het volgende verhaal illustreert het onderscheid overtuigend.

Een klant van een supermarkt loopt mer een boodschappenlijst door de winkel en wordt gevolgd door een detective. De klant pakt de artikelen die op de lijst staan van de rekken en legt die in haar wagen. De detective noteert alles wat de klant pakt. Als ze de winkel verlaten, hebben de klant en de detective dezelfde boodschappenlijst, de functie van de twee lijsten is echter verschillend. De items op de lijst van de klant zijn directieven, die op de lijst van de detective zijn constatieven. Dit blijkt heel duidelijk als men de rol bekijkt, die een vergissing in elk van de twee gevallen heeft. Wanneer de detective, thuisgekomen, zich realiseert dat zij vergeten is de vier palkken koffie die de klant heeft gepakt, te noteren, kan zij die fout eenvoudig herstellen door het item alsnog op te nemen. Als de klant thuis ontdekt dat ze de familiezak chips is vergeten, helpt het doorstrepen daarvan hellaas niet; vermoedelijk kan zij wel rekenen op enkele ferme taalhandelingen van haar kinderen. 
In samenhang met het reduceren van het aantal soorten van illocuties breng ik nog een tweede belangrijke reductie aan met betrekking tot de communicatie in organisaties. In de taalfilosofische analyse is het voldoende een zender en een ontvanger van een feit te onderkennen als respectievelijk de actor die spreekt of schrijft en de actor die luistert of leest. Een communicatiemodel van een organisatie dat op deze onderscheiding is gebaseerd, bevat echter ook uitwisselingen van informatie die niet essentieel en dus overbodig zijn. Het volgende voorbeeld moge verduidelijken wat ik bedoel.

Als een klant van Bak \& Eet informeert naar de prijs van de Histoire d'O., zal hij van de verkoper daarop waarschijnlijk een antwoord krijgen. Er vindt dan dus een communicatie plaats, waarbij de verkoper de rol van zender inneemt en de klant die van ontvanger. De verkoper is echter, zoals gezegd, niet degene die de prijzen vaststelt, dat is de directeur. De taalhandeling van de verkoper brengt dus eigenlijk niets nieuws voort; het is namelijk niet de originele mededeling van een toestandsverandering, maar een reproduktie ervan. Omdat zo'n taalhandeling geen nieuw feit produceert, noem ik hem een improduktieve taalhandeling. Het verrichten van improduktieve taalhandelingen heet bijgevolg improduktieve communicatie. Improduktieve communicatie is een kwestie van uitvoering en hoort dus niet thuis op het conceptuele niveau. Daarmee zeg ik overigens niet dat bijwoorbeeld het doorgeven van prijzen door verkopers geen wenselijke wijze van uitvoering zou zijn. Het punt is dat het een uitvoeringszaak is en dat de essentiële communicatie die tussen directeur en klant is. Een andere wijze van uitvoering van dezelfde communicatie is bijvoorbeeld het verstrekken van een prijslijst.

Dit is nou precies wat $u$ al wel eens dacht: er wordt in organisaties beel veel improduktief gecommuniceerd. En, 
erger nog, uit eigen ervaring weet $u$ dat daarmee fouten worden geïntroduceerd. De ene persoon zegt gewichtig dat iets zó is, en de andere ontkent dat met kracht. Ook herinnert u zich nu weer ww ingehouden woede over die stupide reactie die u soms krijgt aan een loket of een informatiebalie: "Waarom wilt u dat weten?"

$U$ ziet in dat in grote organisaties, en misschien nog meer daarbuiten, veel actoren alleen maar de functie wan koevier vervullen. En aan koeriers hebt u nu eenmaal geen boodschap.

Een produktieve taalhandeling kan nu worden gedefinieerd als een taalhandeling waarvan de zender de originator van het gecommuniceerde feit is en de ontvanger de (uiteindelijk) geadresseerde. Het is overigens mogelijk dat er twee of meer geadresseerden zijn.

Door van elk feit alleen de originator en de geadresseerde( $n$ ) te beschouwen wordt alle improduktieve communicatie geëlimineerd.

\section{Samenvatting}

De taalfilosofische analyse van communicatie lijkt een bruikbare gemeenschappelijke basis te bieden voor informatiemodellen en procesmodellen op het conceptuele niveau. Alleen produktieve taalhandelingen kunnen op dit niveau voorkomen. Figuur 2 toont op een grafische wijze de definitie van een (produktieve) taalhandeling.

De toestand van de wereld wordt niet alleen veranderd door het verrichten van fysische handelingen, maar ook, en zelfs in belangrijke mate, door het verrichten vari taalhandelingen. 


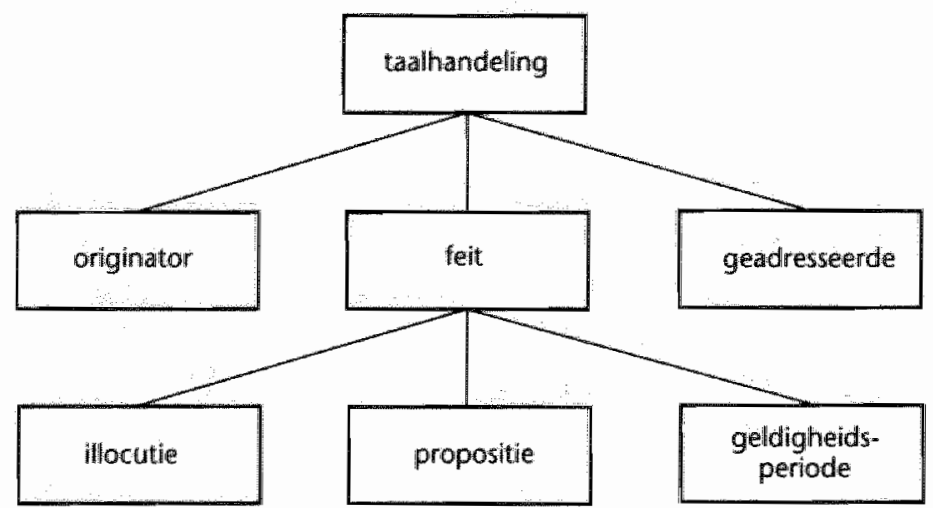

Figuur 2

Het primaire proces van een institutionele organisatie blijkt uit lóuter taalhandelingen te zijn opgebouwd:

zo gezegd, zo gedaan. 


\section{Het conceptuele procesmodel}

Een conceptueel procesmodel is een model van een subjectsysteem. Om het communiceren der actoren op een conceptueel niveau uit te beelden voer ik de idee van een feitenbank in. Een feitenbank, of kortweg bank, is een (conceptuele) opslagplaats voor feiten. De verzameling van alle feiten die een bank kan bevatten, heet de opslagbasis van de bank. De verzameling feiten die een bank op een bepaald moment bevat, heet de inhoud van de bank. Deze is dus altijd een deelverzameling van de opslagbasis.

Actoren kunnen op twee manieren zijn verbonden met banken, namelijk door middel van muteerverbindingen en door middel van inspecteerverbindingen. $\mathrm{Er}$ is een muteerverbinding tussen een actor en een bank indien de actor originator is van de feiten in de bank. De bank wordt een muteerbank van de actor genoemd. Er is een inspecteerverbinding tussen een actor en een bank indien de actor geadresseerde is van de feiten in de bank. De bank wordt een inspecteerbank van de actor genoemd. Op grond van de onderscheiding in directieve feiten en constatieve feiten bestaan er twee soorten banken: directievenbanken en constatievenbanken.

Her ligt voor de hand, maar noodzakelijk is dat niet, de directievenbanken en de constatievenbanken zo te definiëren dat de opslagbases klassen van feiten zijn. Een klasse van feiten is de verzameling van feiten die hetzelfde werkwoordelijke deel in hun proposities hebben. De feiten heten van hetzelfde type te zijn. Een voorbeeld van een feittype is de prijs van een artikel. Een voorbeeld van een feit van dat type is 'De prijs van de Bosbessentaart is vanaf volgende week 
$f 11,50^{\prime}$. De strekking van de voorgaande opmerking is dus dat het voor de hand ligt de prijzen van alle artikelen in één bank te bewaren.

De (produktieve) communicatie in een subjectsysteem en tussen een subjectsysteem en zijn omgeving kan nu worden voorgesteld als een netwerk van actoren, die onderling zijn verbonden door middel van banken, zodanig dat elke actor originator of geadresseerde is (of beide) van de feiten in elke bank waarmee hij is verbonden. Zo'n netwerk kan grafisch worden uitgebeeld in een zogeheten Communicatie Structuur Diagram (CSD). In een CSD worden actoren voorgesteld door een vierkant, directievenbanken door een cirkel en constatievenbanken door een ruit. Actoren enerzijds en banken anderzijds worden door middel van pijlen met elkaar verbonden. Een pijl van een actor naar een bank stelt een muteerverbinding voor, een pijl van een bank naar een actor representeert een inspecteerverbinding. Figuur 3 laat de CSD's zien van de twee meest eenvoudige netwerken.

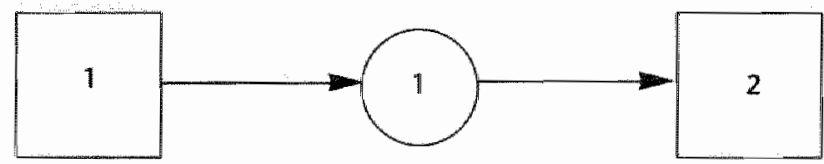

$$
S 1=D 1 \cap A 2
$$

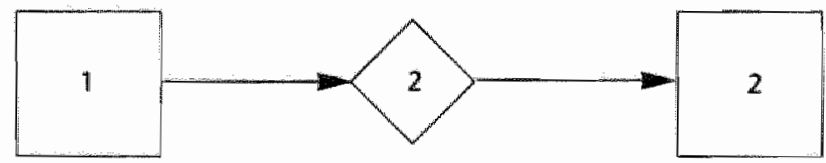

$$
52=\mathrm{Cl} \cap \mathrm{N} 2
$$

\section{Figuru 3}


Her bovenste diagram drukt uit dat de actor 'klanten' directieven genereert van het type 'klantorder", waarvan de actor 'winkel' de geadresseerde is. De directievenbank 'klantorders' is muteerbank van de actor 'klanten' en inspecteerbank van de actor 'winkel'. Het onderste diagram drukt uit dat de actor 'directeur' constatieven genereert van het type 'prijs', waarvan de actor 'klanten' een geadresseerde is. De constatievenbank 'prijzen' is een muteerbank van de actor 'directeur' en een inspecteerbank van de actor 'klanten'.

Op grond van de twee soorten feitenbanken via welke actoren kunnen zijn verbonden, onderscheid ik twee soorten beinvloedingen tussen actoren: dirigeren en conditioneren. De actor 'klanten' in het bovenste diagram dirigeert de actor 'winkel', omdat de klanten directieven produceren die de winkel gehouden is uit te voeren. De actor 'directeur' in het onderste diagram conditioneert de actor 'klanten', omdat de directeur constatieven produceert die het gedrag van de klanten mede bepaalt.

Om het gedrag van de actoren nauwkeurig te beschrijven is het nodig nog enkele nieuwe termen te introduceren.

De gezamenlijke inhoud van de inspecteerbanken van een actor heet de data van de actor ('data' betekent 'de dingen die gegeven zijn'; het enkelvoud is 'datum'). De data van een actor op een bepaald moment zijn dus alle tot op dat moment gegeven feiten. De gezamenlijke inhoud van de muteerbanken van een actor heet de facta van de actor (facta' betekent 'de dingen die gedaan of gemaakt zijn'; het enkelvoud is 'factum'). De facta van een actor op een bepaald moment zijn dus alle tot op dat moment gegenereerde feiten. De kwalificaties data en facta zijn rolaanduidingen; ze hebben dus een relatief karakter. Eenzelfde feit kan voor een actor tegelijkertijd datum en factum zijn. Dat is het geval als hij een feit heeft geproduceerd, dat hij later zelf weer gebruikt. 
De data van een actor op een bepaald moment beschrijven een deel van de toestand van het objectsysteem dat het referentiedomein is van het subjectsysteem waarvan de actor deel uitmaakt. De directieven in deze data noem ik gezamenlijk de agenda van de actor ('agenda' betekent 'de dingen die gedaan moeten worden'). De verzameling van alle directieven die kunnen voorkomen in de agenda van een actor, heet de agendabasis van de actor. De constatieven in de data noem ik gezamenlijk de noscenda van de actor ('noscenda' betekent 'de dingen die gekend moeten worden'). De verzameling van alle constatieven die kunnen voorkomen in de noscenda van een actor, heet de noscendabasis van de actor.

$U$ moet bier even aan wennen, maar het spreekt $u$ wel aan. $U$ concludeert dat bijvoorbeeld een wijziging van het produktieplan van de Histoire d'O. voor de komende week een agendawijaiging is voor de bakkerij, en $u$ stelt met instemming vast dat dit words gezien als een verandering van de toestand van Bak of Eet. $U$ concludeert ook dat een prijswijziging van bijvoorbeeld de Christiane $F$, ingalande volgende maand, een noscendawijziging is voor de klanten, en andermaal stelt u met instemming vast dat dit als een toestandsverandering wordt beschouwd.

Het proces dat zich afspeelt in een subjectsysteem, schrijdt voort doordat de actoren directieven uitvoeren. Het directief dat een actor op een bepaald ogenblik in uitwoering neemt, heet de actie van de actor op dat moment. Dit is altijd één van de geldige directieven in de agenda van de actor. Indien bijvoorbeeld in de agenda van de actor 'bakkerij' het directief voorkomt, inhoudende de produktie van 28 Bramenvlaaien op vrijdag 7 september, dan kan die produktie op elk tijdstip van die dag ter hand worden genomen. Het is in principe toegestaan dat een actor twee of meer directieven tegelijker- 
tijd in uirvoering neemt. De actie bestaat dan uit een aantal directieven.

Het uitwoeren van een actie heet een gedrag. De mogelijke gedragingen van een actor zijn bepaald door zijn zogeheten gedragsbasis; dat is een verzameling gedragsregels die de vorm hebben van een produktieregel bestaande uit een inspectiedeel en een mutatiedeel. Het inspectiedeel bevat een aantal voorwaarden waaraan de data van de actor, dus de agenda en de noscenda, op dat moment moeten voldoen; het mutatiedeel specificeert een aantal te genereren directieven en constatieven. Indien aan de voorwaarden van het inspectiedeel is voldaan, worden de mutaties gegenereerd. Een (informele) beschrijving van een mogelijke gedragsregel voor de actor 'Verkoop' van Bak \& Eet is de volgende:
ALS
er een klantorder voor 2 Innocentia's is
en er zijn minstens 2 Innocentia's in voorraad
en de klant is bereid de verkoopsom te betalen
DAN
haal 2 Innocentia's uit de voorraad
en ruil die voor de verkoopsom.

De gegenereerde directieven noem ik de dirigenda ('dirigenda' betekent "de dingen die uitgevaardigd moeten worden'; het enkelvoud is "dirigendum') en de gegenereerde constatieven noem ik de constanda ('constanda' betekent 'de dingen die moeten worden vastgesteld'; het enkelvoud is 'constandum'). De dirigenda en de constanda kunnen pas effect hebben als ze door een taalhandeling van de actor bekend worden gemaakt: ze moeten worden uitgesproken (of opgeschreven). Dit is een noodzakelijke handeling, waarachter een interessante filosofische vraag schuilt: kunnen dingen die niet bekend zijn toch bestaan? 
De bekendmaking van een dirigendum resulteert onmiddellijk in een verandering van de agenda van elke actor waarvoor geldt dat het betreffende directief behoort tot de agendabasis. Dus, als het hoofd van de bakkerij een directief bekendmaakt, inhoudende de produktie van 28 Bramenvlaaien op 7 september, dan wordt dit directief meteen opgenomen in de agenda van de bakkerij.

De bekendmaking van een constandum resulteert onmiddellijk in een verandering van de noscenda van elke actor waarwoor geldt, dat het betreffende constatief behoort tor de noscendabasis. Als dus op een bepaald moment door de directie het constatief wordt bekendgemaakt, inhoudende dat de prijs van de Megatrends in september $\mathrm{f} 10$,- is, dan wordt dit constatief meteen opgenomen in de noscenda van de klanten.

Een precieze en formele wijze van specificeren van een gedragsbasis is te vinden in [Dietz, 1990]. Met behulp van de zojuist besproken definitie van het gedrag van actoren kan een preciezer begrip wan een conceptueel procesmodel worden verkregen (zie ook figuur 4).

Indien er een overlap is van de dirigendabasis (D1) van een actor 1 en de agendabasis (A2) van een actor 2, dan bestaat er een directievenbank, zeg 1, waarvan de opslagbasis (S1) gelijk is aan die overlap. Deze bank wordt gemuteerd door actor 1 en geïnspecteerd door actor 2 .

Indien er een overlap is van de constandabasis (C1) van een actor 1 en de noscendabasis (N2) van een actor 2 , dan bestaat er een constatievenbank, zeg 2, waarvan de opslagbasis (S2) gelijk is an die overlap. Deze bank wordt gemuteerd door actor 1 en geïnspecteerd door actor 2 . 


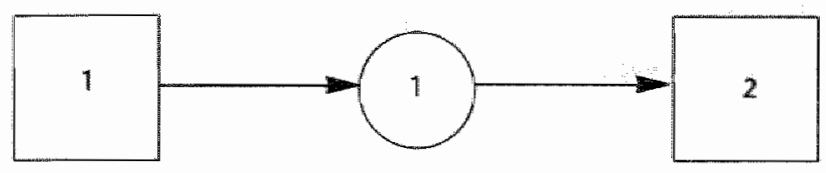

$51=\mathrm{Din} A 2$

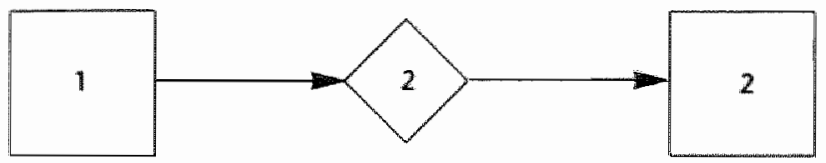

$52=\operatorname{CInN} 2$

Figuur 4

Een actor is geadresseerde van elk directief in zijn agendabasis en van elk constatief in zijn noscendabasis. Een actor is originator van elk directief in zijn dirigendabasis en wan elk constatief in zijn constandabasis.

Her kan voorkomen dat een actor een bank muteert én inspecteert. Dat is het geval als er een overlap bestaat van de agendabasis en de dirigendabasis of van de noscendabasis en de constandabasis. Er is dan sprake van respectievelijk zelfdirigering en zelfconditionering. Door middel van zelfdirigering kan men bijvoorbeeld periodieke activiteiten modelleren. Zelfconditionering is bijvoorbeeld het onthouden van kennis of het hebben van een privé-archief.

Een conceptueel procesmodel (CPM) is dus een model van een subjectsysteem dat primair de agendabasis, de noscendabasis, de dirigendabasis, de constandabasis en de gedragsbasis van elke actor beschrijft. Uit de overlappen van de agendabases en de dirigendabases, en van de noscendabases en de constandabases volgt de noodzakelijke commmunicatie tussen de 
actoren onderling, en met de (actoren in de) omgeving van het subjectsysteem.

De diagrammen in figuur 4 suggereren wellicht dat in het inspectiedeel van de gedragsregels die het gedrag van actor 2 bepalen, dezelfde feiten voorkomen als die welke behoren tot de opslagbasis van directievenbank 1 en tot die van constatievenbank 2. Dat is echter niet noodzakelijk, hetgeen aan de hand van het diagram in figuur $5 \mathrm{zal}$ worden toegelicht.

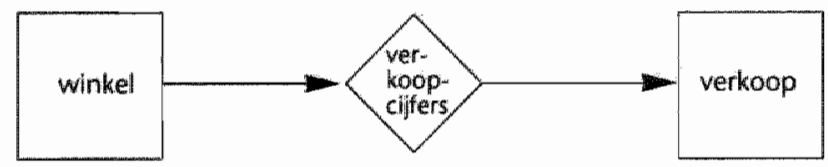

Figuur 5

De actor 'winkel' produceert als gevolg van het uitvoeren van zijn taken constatieven, zoals de onderstaande:

'Op 25 augustus is er een Innocentia verkocht aan mevr. De Vries.'

'Op 2 september zijn er drie Christiane F.'s verkocht aan Ds. van de Broek.'

'Op 7 september zijn er twee Megatrends verkocht aan mevr. De Vries.'

Tot de taken van de actor 'Verkoop' behoort het maandelijks produceren van een bijstelling van het verkoopplan. Daarbij gebruikt men onder andere een overzicht van de verkoop per artikelgroep over de afgelopen zes maanden. Dit overzicht wordt door de afdeling Informatie \& Statistiek gemaakt en in de vorm van een staafdiagram gepresenteerd. 
De feiten die daardoor worden uitgedrukt, zijn de feiten die voorkomen in het inspectiedeel van de gedragsregels van de actor 'Verkoop' (de presentatievorm is op het conceptuele niveau uiteraard niet relevant).

Deze werkzaamheden van de afdeling Informatie \& Statistiek nu vindt men in het diagram van figuur 5 niet terug. De reden hiervoor is dat het produceren van zo'n staafdiagram alleen maar een deductie van feiten is uit de beschikbare elementaire verkoopfeiten en dus een improduktieve handeling: de toestand van de wereld verandert er niet door.

Evenals de reproduktie van feiten komt de deductie van feiten dus niet voor in een conceptueel procesmodel.

$U$ kunt niet nalaten bier even te gniffelen. De afdeling Informatic of Statistiek, en bijgevolg elke informatieverwerkende of administratieve afdeling, doet dus improduktief werk! Belangrijker dan deze constatering is echter het $n u$ bij u opdoemende inzicht dat produktief en improduktief relatieve kwalificaties zijn. Ze zijn afhankelijk van wat men als subjectsysteem definieert. Indien men bijvoorbeeld de afdeling Informatie of Statistiek als subjectsysteem neemt, zal blijken dat er veel produktieve handelingen door de actoren in deze afdeling worden verricht, madr ook natuurlijk improduktieve. In dit verband schiet $u$ bet woord 'meta-informatiesysteem' te binnen. Met dit woord wordt in diverse leerboeken een informatiesysteem over een informatiesysteem aangeduid. Afgezien van bet feit dat de term 'meta' niet van toepassing en dus verwarrend is, is bet voor u duidelijk geworden dat er geen gronden zijn voor een speciale naam: het gaat om het beschouwen van een informatiesysteem als een subjectsysteem, niet minder madar ook niet meer! 
Aan de hand van het CSD van een subjectsysteem blijkt het lokaliseren van informatiesystemen een eenvoudige zaak. Bovendien komt uit een CSD duidelijk het onderscheid naar voren tussen twee principieel verschillende soorten van informatiesystemen: communicatie-ondersteunende systemen en beslissingsondersteunende systemen.

Een communicatie-andersteunend systeem is een informatiesysteem dat, geheel of gedeeltelijk, de opslag van feiten in een bank, de reprodukrie van feiten, en het transport van feiten tussen de bank enerzijds en de originatoren en geadresseerden anderzijds, ondersteunt.

Een beslissingsondersteunend systeem is een informatiesysteem dat, geheel of gedeeltelijk, het nemen van beslissingen, i.c. het uitvoeren van gedragsregels, door actoren ondersteunt. Het deduceren van feiten wordt ook hiertoe gerekend.

In de praktijk zijn informatiesystemen, zoals bijvoorbeeld een salarissysteem of een produktiebesturingssysteem, meestal mengvormen van (elementaire) communicatie-ondersteunendè en/of beslissingsondersteunende systemen.

Onvermijdelijk gaan uw gedachten nu naar die basisopvatting van een informatiesysteem, die $u$ in haast elk leerboek aantreft, namelijk die van een systeem dat data transformeert naar, of veredelt tot, informatie.

Voor $u$ was deze opvatting altijd al een onvruchtbare, en in die overtuiging wordt $u$ nu alleen maar gesterkt. Het transformatiebeeld vertroebelt een goed begrip van informatiesystemen. Niet alleen gaat het voorbij aan bet principiële onderscheid tussen communicatie-ondersteunende en beslissingsondersteunende systemen, maar bovenal roept het de foutieve vergelijking op met een fysisch produktieproces, wadrin grondstoffen worden getransformeerd tot eindprodukten. 
Zo'n vergelijking vindt u misleidend om twee redenen. Allereerst is bet zo, dat zowel de invoer als de witvoer van een informatiesysteem feiten representeent over eenzelfde objectsysteem. Primair bestadn de invoer en de uitvoer dus uit dingen van dezelffe soort.

Vervolgens is er geen verband tussen (de betekenis van) een feit en de bandelingen die nodig zijn om de representatie ervan voort te brengen. Dat geldt niet alleen voor de originele produktie van feiten, maar ook voor reproduktie en deduktie.

Het praktische belang van conceptuele procesmodellen ligt vooral in de eerste fase van de ontwikkelingscyclus van een informatiesysteem, waarin een analyse van het subjecrsysteem wordt uitgevoerd. De huidige praktijk daarbij is dat men uitgaande van het logische procesmodel van de huidige situatie (en de actuele problemen) het logische procesmodel van een nieuwe situatie ontwerpt (waarin de problemen zijn 'opgelost'). In deze belangrijke fase wordt men echter gemakkelijk gehinderd en misleid door de aanwezigheid van informatiereproducerende en informatiededucerende activiteiten. Omdat beide soorten activiteiten in een CPM zijn geëlimineerd, biedt een CPM een geschikt uitgangspunt voor ontwerp, namelijk een waarin de ontwerper van de nieuwe informatievoorziening de grootst mogelijke vrijheid heeft. In figuur 6 is het verschil tussen de bestaande praktijk en de voorgestelde nieuwe in beeld gebracht. De nieuwe werkwijze is door middel van ononderbroken pijlen aangegeven, terwijl ter vergelijking de huidige werkwijze door een onderbroken pijl is aangeduid. 


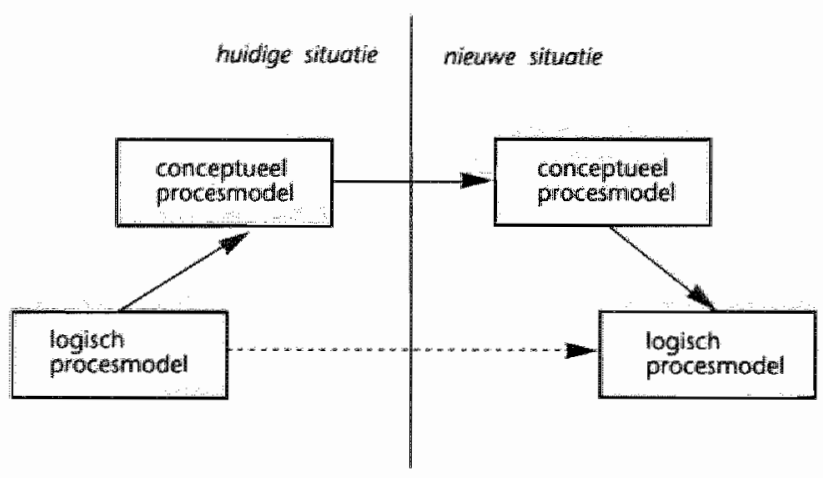

Figutur 6

$U$ bent hier even bedwusd van, maar ziet gelukkig wel het belang van conceptuele procesmodellen voor de informatiekundige systeemanalyse in. U legt terecht het verband met gedachten die u eerder had over institutionele organisaties. Ook gaan ww gedachten naar het hoofdstuk in Yourdons laatste boek 'Modern Structured Analysis' [Yourdon, 1989], waarin de idee van een essentieel model wan een systeem wordt besproken. $U$ ziet in dat het conceptuele procesmodel precies dat model is en dat Yourdon er niet in is geslaagd het idee een bruikbare concretisering te geven. $U$ neemt zich voor thuis nog eens rustig over conceptuele procesmodellen na te denken; er zijn teveel gedachten die on een nieuwe ordening vragen.

Het CPM in de nieuwe siruatie verschilt van dat in de huidige situatie indien het subjectsysteem zelf is veranderd, bijvoorbeeld doordat de taakstelling van een actor is gewijzigd.

Dit uit zich in een CPM doordat de gedragsbasis van een aanal actoren wordt veranderd. Deze soort verandering van een systeem wordt evolutie genoemd. 


\section{Samenvatting}

Een conceptueel procesmodel laat de essentiële activiteiten in een subjectsysteem zien, dat wil zeggen de activiteiten die tot veranderingen van de toestand van de wereld leiden. In het bijzonder komen reproduktie en deducrie van informatie er niet in voor. Ten gevolge daarvan bestaat er precies én conceptueel procesmodel voor elk subjectsysteem, terwijl er in principe een aantal modellen kandidaat is voor de beschrijving op het logische en het fysische niveau.

Een conceptueel procesmodel is een netwerk van actoren en feitenbanken, via welke de actoren communiceren. Een actor kan een bank inspecteren en/of muteren. Op grond van het onderscheid tussen directieven en constatieven worden er directievenbanken en constatievenbanken onderscheiden. De gezamenlijke inhoud van de directievenbanken die een actor inspecteert, heet de agenda van de actor. De gezamenlijke inhoud van de constatievenbanken die de actor inspecteert, heet de noscenda van de actor.

Het gedrag van een actor is bepaald door een verzameling produktieregels, de gedragsbasis geheten. Een produktieregel bestaat uit een inspectiedeel en een mutatiedeel. Het inspectiedeel stelt voorwaarden aan de agenda en de noscenda, het mutatiedeel specificeert de te genereren directieven (de dirigenda) en constatieven (de constanda). De dirigenda en de constanda, die een actor als resultaat van zijn handelen genereert, worden pas van kracht als hij ze uitspreekt:

zo gezegd, zo gedatn. 


\section{Het conceptuele informatiemodel}

Een conceptueel informatiemodel is een model van een objectsysteem. De kennis van een objectsysteem is een totaliteit van feiten [Wittgenstein, 1982]. In deze totaliteit van feiten kunnen drie elkaar uitsluitende deelverzamelingen worden onderscheiden, overeenkomend met drie kennisniveaus: het toestandsniveau, het schemaniveau en het metaniveau.

De toestand van een objectsysteem is vastgelegd in de gezamenlijke data van de actoren in het bijbehorende subjectsysteem. In de loop der tijd verandert de toestand. Zo'n verandering wordt een transitie genoemd. Een transitite komt dus overeen met een wijziging van de data van een aantal actoren in het subjectsysteem. Zo'n wijziging wordt veroorzaakt door actoren in het subjectsysteem of door actoren in de omgeving daarvan. Men dient dus een onderscheid te maken tussen het proces van een objectsysteem, zijnde de opeenvolging van transities, en het proces van een subjectsysteem, zijnde de opeenvolging van gedragingen van actoren. Het proces van een objectsysteem schrijdt voort doordat de data van de actoren in het subjectsysteem veranderen, het proces van een subjectsysteem schrijdt voort doordat de facta van die actoren veranderen. Alleen voor zover facta ook data zijn, komt een gedrag van (een actor in) een subjectsysteem overeen met een transitie in het bijbehorende objectsysteem.

In dit hoofdstuk is de aandacht vooral gericht op het beschrijven van de kennis op het schemaniveau en op het metaniveau. Om dit niet al te gecompliceerd te maken beperk ik me 
tot het beschrijven van proposities. De illocutie en de geldigheidsperiode van feiten worden dus buiten beschouwing gelaten.

Het toestandsniveau betreft alle kennis die specifiek is voor een bepaalde toestand. Met andere woorden, de feiten die in de ene toestand gelden, hoeven dat nog niet in de andere te doen. Figuur 7 geeft enkele voorbeelden van proposities op het toestandsniveau in de wereld van Bak \& Eet.
'De Megatrends kost $f 10,-$ '
'De Bosbessentaart kost $f 11,50 .{ }^{\text {' }}$
'De Bramenvlaai kost $f 1,75$.'
'De Christiane F. kost $f$ 8,50.'

Figur 7

Het schemaniveau betreft alle kennis die specifiek is voor een bepaalde wereld, maar generiek voor alle toestanden waarin die wereld zich kan bevinden. Men kan dat ook als volgt zeggen: de kennis over een toestand van de wereld die algemeen is voor die wereld en dus voor elke toestand geldt, wordt geëxtraheerd en op het schemaniveau vastgelegd.

Het metaniveau betreft alle kennis die generiek is voor alle werelden. Deze kennis wordt verkregen door extractie van de algemene kennis die er bestaat op het schemaniveau.

Uit de in figuur 7 gegeven voorbeelden van proposities kan de volgende algemene kennis worden afgeleid. Allereerst valt op te merken dat het werkwoordelijke deel in elk van de proposities hetzelfde is. Men zegt dan dat deze proposities van hetzelfde propositietype zijn. Een toepasselijke naam voor dit propositietype is 'artikelprijs'. Elk van de proposities heet een instantiatie van het propositierype 'artikelprijs'. Een 
verzameling instantiaties van een bepaald propositietype heet een populatie van dat propositietype. Vervolgens geldt voor elke propositie in figuur 7 dat hij betrekking heeft op twee objecten, die ieder een eigen rol vervullen. De rol van het eerste object is die van datgene wat een prijs heeft, de rol van het tweede object is die van datgene wat de prijs van iets is. (N.B. Dat het aantal objecten hier twee is, is louter toeval. Er zijn ook proposities die op één, op drie, op vier etc. objecten betrekking hebben.) Tenslotte kan worden opgemerkt dat de objecten die in elk van de proposities dezelfde rol vervullen, tot dezelfde klasse van objecten behoren. Het eerste object behoort steeds tot de klasse 'artikelen' en het tweede tot de klasse 'bedragen'. Een klasse is de verzameling van alle objecten die van hetzelfde objecttype zijn. Men spreekt daarom ook wel van respectievelijk de objecttypen 'artikel' en 'bedrag".

Een bepaald object kan overigens tegelijkerrijd tot een willekeurig aantal klassen behoren.

De laatste opmerking leidt bij $u$ baast vanzelf tot een nieuwe bepaling van het begrip 'entiteit', die u alleen ooit bij Ross [Ross, 1975] eerder was tegengekomen: een entiteit is een object met een type. Het tot een klasse behoren van een object is dus essentieel voor het begrip entiteit. $Z o$ zijn bakker Piet, medewerker Piet en oom Piet voorbeelden van entiteiten, terwijl Piet alleen maar een object is, dat wil zeggen een ding los van zijn eigenschappen.

De beschrijving van de kennis op het schemaniveau heet een (conceptueel) schema. Voor het grafisch representeren van een schema blijkt het in figuur 8 uitgebeelde Informatie Structuur Diagram (ISD) erg handig. Dit diagram is ontleend aan de methode NIAM [Nijssen, 1989]. 


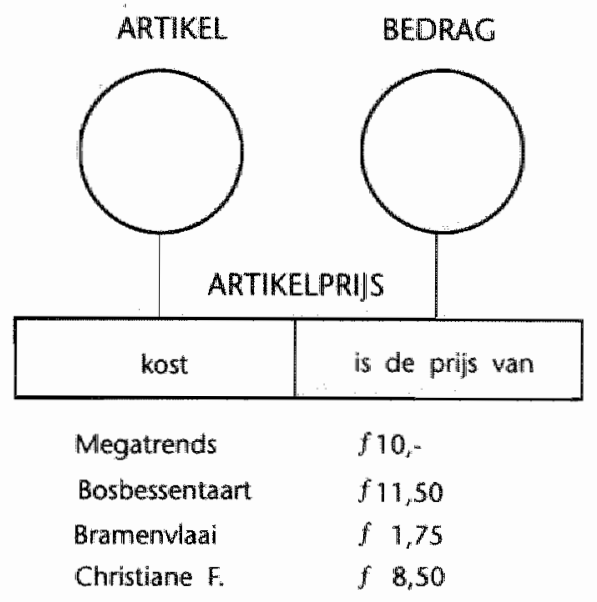

Figuur 8

Een cirkel stelt een klasse van objecten voor. Het type van de klasse staat (in hoofdletters) erboven genoteerd. Elke rechthoek representeert een rol van het propositietype en is verbonden met de objectklasse, waarvan de elementen die rol kunnen vervullen. Het propositietype is, in hoofdletters, vermeld boven de aaneengeschakelde rechthoeken.

Het handige van deze diagramtechniek is dat men eenvoudig een populatie van het propositietype ter illustratie kan toevoegen. Dat is in figuur 8 ook gedaan. Het reconstrueren van de formuleringen in de natuurlijke taal uit dit diagram is niet moeilijk.

Doordat elke rol expliciet is benoemd, is het ook eenvoudig de omgekeerde formulering van de proposities te reconstrueren. Voor de eerstgenoemde instantiatie bijvoorbeeld is dat 'f 10 , - is de prijs van de Megatrends'. 
Het schemaniveau is restrictief met betrekking tot het toestandsniveau. Dat wil zeggen dat op het toestandsniveau geen proposities kunnen voorkomen, waarvan de algemene structuur (het 'schema') niet is vastgelegd op het schemaniveau. Men zegt ook wel dat de kennis op het schemaniveau de definitie is van de toestandsruimte van de beschreven wereld; dat is de verzameling van alle mogelijke toestanden. Hoewel de definitie van de diverse propositietypen de kern van de kennis op het schemaniveau vormt, zijn er in het algemeen meer generieke feiten, meestal beperkingsregels genoemd, te vinden. Het effect van deze beperkingsregels is altijd de inperking van het aantal mogelijke of toelaatbare populaties van propositietypen. Een voorbeeld van zo'n regel is dat een artikel op elk moment niet meer dan één prijs kan hebben. Deze regel sluit uit dat in een populatie van het betreffende propositietype bijwoorbeeld de proposities "De Christiane F. kost $f 8,50$ ' en 'De Christiane F. kost $f 11$,-' voorkomen. Generieke kennis kan bijvoorbeeld ook voortkomen uit verbanden tussen objectrypen onderling. Een bekend voorbeeld van zo'n verband is de subtype-relatie ofwel de generalisatie/specialisatie-abstractie. Door zo'n verband drukt men uit dat de klasse van een objecttype altijd een deelverzameling is van de klasse van een ander type. Zo kan men in het informatiemodel van Bak \& Eet bijvoorbeeld uitgebeeld willen hebben, dat bakker een subtype is van medewerker, naast bezorger en verkoper. Figuur 9 toont het ISD waarin deze kennis is uitgedrukt. 


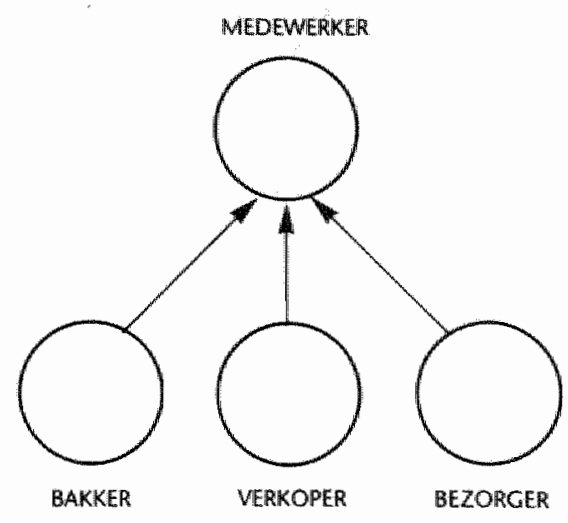

Figuur 9

De pijlen van de objectrypen 'bakker', 'verkoper' en 'bezorger' naar het objecttype 'medewerker' drukken uit dat deze typen subtypen zijn van medewerker. Op het toestandsniveau betekent dit dus, dat de klassen van deze typen altijd deelverzamelingen zijn van de klasse van het type medewerker.

$U$ berinnert zich dat $u$ in dit verband vaak het woord 'overerving' bebt boren vallen. In het gegeven voorbeeld heet het dan dat het type bakker alle eigenschappen van het type medewerker overerfi. Afgezien van het feit dat $u$ die naam niet zo toepasselijk vindt - er is immers geen sprake van een ouder-kind-relatic - merkt $u$ op dat het begrip eigenlijk overbodig is. Het is voldoende te weten dat een object tegelijkertijd tot bijvoorbeeld de klasse bakkers en tot de klasse medewerkers kan behoren, en om die reden zowel de eigenschappen van een bakker als die van een medewerker bezit. 
Een bellangrijk praktisch probleem bij het maken van conceptuele schema's is het verifiëren en het valideren ervan.

Onder het verifiëren van een schema wordt verstaan het nagaan of het schema syntactisch correct is. Men kan een conceptueel schema dat op de hiervoor beschreven wijze is opgesteld, gemakkelijk verifiëren door van elk propositietype een populatie te geven. Het genereren van een populatie kan iedereen die de natuurlijke taal beheerst en die de diagramtechniek begrijpt. Als het niet lukt een populatie te geven van een propositierype, is er iets mis met het schema. De eer van het methodisch gestalte geven van het populeren van propositietypen ofwel het verwoorden van schema's komt toe aan Nijssen [Nijssen, 1989].

Onder her valideren van een schema wordt verstaan het nagaan of het schema semantisch correct is, dat wil zeggen, of alle relevante propositietypen zijn opgenomen en of de aan de populatie van elk propositietype opgelegde beperkingen een juiste afspiegeling zijn van de normen en regels in de werkelijkheid.

Helaas zijn maar zeer weinig methoden voor informatiemodellering gebaseerd op het uitgangspunt, dat een wereld is gedefinieerd door een verzameling feiten. Voor een methode die dat niet is, kan het verifiëren en valideren van schema's vaak een lastige zaak zijn.

$U$ proeft weer even de ergernis die $u$ bekruipt bij het bestuderen van de conceptuele schemas in projectvoorstellen en informatieplannen, maar ook in boeken en tijdschriftartikelen, vantwege de vele fouten die ze bevatten. Bovendien bent u nog steeds een beetje beduusd van de blunders die $u$ recentelijk aantrof in de officiële uitwerkingen van enkele examenopgaven van een universitair onderwijsinstituut. Zoiets is des te storender nu $u$ weet dat bet alle- 


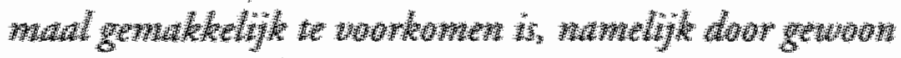
con guede methode ic gebruiken.

Op dezelfde wiyze warop men uit de kennis op het toestandsniveau de algemeen geldende ofwel generieke kennis

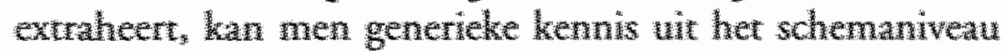
extraheren. Anders gezegd, door her bestuderen van wootbeelden van schemas wind men de regels die voor alle schema's gelden. Wat men dan dus doet, is de elementen war elk schema beschowwen als instantiaties van propositieryen op het metaniweau. Als voorbeeld van een propositietype op het metaniveau in ingur 10 de defnitie van de subtype-relatie russen objectrypen weergegeven, alsmede de populatie die in fgur 9 als diagram op het schemanvea is uitgebeld.

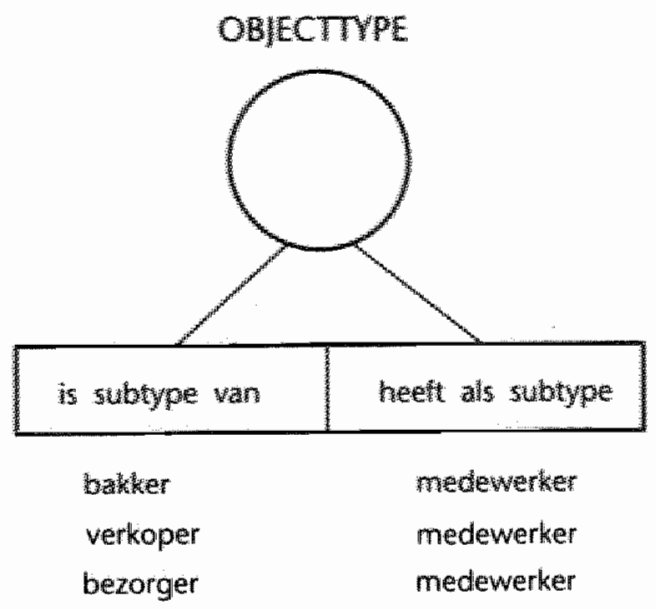

Figuur 10 
De volgende ontdekking leidt $u$ nu even af. Hoewel de idee van generalisatie en specialisatie u duidelijk was, hebt $u$ toch steeds iets merkwaardigs gevonden aan de manier waarop het Entiteit Relatie Model IOpen Universiteit, 19887 deze kennis in een conceptueel schema representeert, namelijk als een relatie. Pogingen om door instantiatie een subtype-relatie te verifiëren leverden altijd vreemde resultaten op en hadden $u$ al wantrouwig gemaakt. Ook was het u opgevallen dat deze, meestal als 'is_een' (Engels: 'is$\left.a^{3}\right)$ aangeduide, relatie als enige twee of meer keren in één schema kon woorkomen. U ziet nu glashelder wat er mis is. Natuurlijk kan er van een 'is_een'-relatie in een conceptueel schema geen zinnige instantiatie worden gevonden! Het is namelijk geen relatie met instantiaties op bet toestandsniveau, maar het is zelf een instantiatie van een relatie op het metaniveau!

$U$ merkt op, dat in bet ISD propositietypen en instantiaties wan propositietypen op het schemaniveau netjes worden onderscheiden door het gebruik van verschillende symbolen. U neemt zich voor de propagandisten van de methoden waarin dat onderscheid niet wordt gemaakt, toch eens op bun slordigheid te wijzen.

Zoals het schemaniveau restrictief is ten aanzien van het toestandsniveau, zo is het metaniveau restrictief ten aanzien van het schemaniveau. Door de kennis op het metaniveau wordt dus de verzameling van alle mogelijke schema's, de schemaruimte, gedefinieerd. Vanwege deze eigenschap wordt de beschrijving van de kennis over een wereld op het metaniveau ook wel de zelfbeschrijving van de modelsoort genoemd, en noemt men een modelsoort ook well een metamodel. De eigenschap van een modelsoort, dat hij in zichzelf kan worden beschreven, is een indicatie van zijn algemene toepas- 
baarheid. Bovendien verschaft hij de basis voor het bewaren van alle kennis over een wereld in één model.

\section{Samenvatting}

De kennis over een wereld is een totaliteit van feiten. Deze kennis kan worden geordend naar drie onderscheiden niveaus: het toestandsniveau, het schemaniveau en het metaniveau. Het toestandsniveau betreft de kennis die specifiek is voor een bepaalde toestand, het schemaniveau betreft de kennis die specifiek is voor een wereld, maar generiek voor elke toestand van die wereld, en het metaniveau betreft de kennis die specifiek is voor een modelsoort, maar generiek voor elk schema in die modelsoort.

De beschrijving van de kennis op het schemaniveau heet een (conceptueel) schema. Het nagaan van de syntactische correctheid van een schema heet het verifieren van een schema, het nagaan van de semantische correctheid wordt valideren genoemd. Alleen van schema's die zijn uitgedrukt in een modelsoort die is gebaseerd op feiten als basiselementen van kennis, is het verifiëren en valideren een eenvoudige zaak. Een effectieve techniek hiervoor is het verwoorden van een schema:

zo gezegd, zo gedaan.

\section{Intermezzo}

De opdracht van Bak \& Eet hebt u inmiddels afgerond. Na enige tijd was het u gelukt volgens de principes die u hiervoor bebt geleerd, een conceptueel procesmodel en een conceptueel informatiemodel van het bedrijf te maken. Op 
grond daarvan had $u$ enkele nuttige suggesties gedaan tot verbetering van de informatievoorziening. Uw rapport is helads in een lade terecht gekomen, en daar zal het waarschijnlijk wel altijd blijven. Er heeft zich namelijk een reorganisatie voltrokken binnen Bak of Eet. Er zijn nu twee bakkerijen, één voar de Christiane F, de Bosbessentaart en de Bramenvlaai, en één voor de overige artikelen. $U$ bad zich in bet begin verbaasd over de dagprijs van de Innocentia, maar u kent nu de achtergrond ervan. Deze stamde nog uit de tijd, dat de directeur dacht als ingredienten de restanten van de overige baksels te kunnen gebruiken, aangevuld met specerijen die bij gratis van een beuriende mogendheid betrok. Oorspronkelijk had bij de Innocentia namelijk bedacht als een variant op de Bosbessentaart, doch in die vorm heeft het nooit willen gedijen. Uit het oogpunt van marketing leek het daarom beter de Innocentia een eigen smaak te geven. Inmiddels is dat gebeurd en komt de verkoop ervan op gang. De prijs van de Innocentia wordt nu op dezelfde wijze bepaald als die waarop de prijzen van de andere artikelen worden vastgesteld. 


\section{Informatiekundig onderwijs en onderzoek}

Voor de eerste bekleder van een leerstoel is het gebruikelijk, dat hij in zijn inaugurele rede aandacht besteedt aan de plannen in het onderwijs en het onderzoek. Graag wil ik dit gebruik in ere houden.

Er ziln twee organisatorische structuren waarin het informatiekundige onderwijs en onderzoek zijn ingebed: de secrie Informatie, ofwel $\mathrm{BI}_{\mathrm{K}}$, van de vakgroep Bedriffseconomie en de projectgroep $2 \mathrm{E}$ (Informatiekunde en Informatica in de Economie). Van de sectie Informatie maken thans acht personen deel uit. De projectgroep $12 \mathrm{e}$ heeft als functie het coördineren van de activiteiten van de sectieleden en die van anderen, met name de leden van de groep Besliskunde binnen de vakgroep Kwantitatieve Economie onder leiding van mijn collega Kolen, en die van de groep Accountancy van de sectie Berichtgeving onder leiding van mijn collega Beek. Een jaar geleden is aan deze twee structuren een derde toegevoegd, namelijk die van de themagroepen. Een themagroep is een informel werkverband, bestaande uit vijf aे zeven personen, dat als een basiscel dient woor onderwijs en onderzoek in een bepaald deelgebied. Bij de samenstelling van themagroepen wordt ernaar gestreefd sectie-, vakgrocps-en faculteitsgrenzen te overschrijden. De ervaringen met deze organisatievorm zijn tot nu toe veelbelovend. De gedachten die ten grondslag liggen aan de inhoud van deze oratie, zijn in belangrike mate voortgekomen uit de gesprekken in de themagroep Communicatie. Het idee voor deze groep is afkomsrig van Ton van 
Reeken, terwijl Guy Widdershoven, staflid van de Faculteit der Gezondheidswetenschappen, er vanuit zijn filosofische achtergrond een onmisbare bijdrage aan heeft geleverd.

Wat het onderwijs betreft wil ik graag beginnen met het schetsen van enkele gedachten die voor mij als leidraad dienen bij het ontwerp van het daarna te bespreken informatiekundige curriculum.

Een belangrijk en altijd actueel probleem van het onderwijs kan haast niet treffender worden geillustreerd dan door het volgende verhaal van de dierenschool, dat een iets aangepaste versie is van wat ik aantrof in het boekje 'Love' van Buscaglia [Buscaglia, 1972]. Dit verhaal is tegelijkertijd verbijsterend en al te waar. Docenten lachen er steeds weer kostelijk om, maar niemand doet er iets aan. Hier komt het.

Op een dag besloten de dieren in een bos een school te starten. Er werd een curriculumcommissie in het leven geroepen, bestaande uit een haas, een zwaluw, een eekhoorn, een snoek en een mol. De discussie in deze commissie kan als volgt worden samengevat:

De haas stond erop, dat rennen in het curriculum werd opgenomen.

De zwaluw stond erop, dat vliegen in het curriculum werd opgenomen.

De eekhoorn stond erop, dat klimmen in het curriculum werd opgenomen.

De snoek stond erop, dat zwemmen in het curriculum werd opgenomen.

De mol stond erop, dat graven in het curriculum werd opgenomen. 
De commissie, in al haar wijsheid en na ampel beraad, bundelde deze wensen en gaf een studiegids uit. Elk dier was verplicht elk onderdeel te volgen. De eerste jaargang ving aan. Hoewel de haas gemakkelijk een tien haalde voor rennen, was klimmen een groot probleem: hij viel steeds achterover. Al gauw liep hij een vorm van hersenbeschadiging op. Hij haallde voortaan met rennen niet meer dan een vijf, en voor klimmen bleef de score een één voor de moeite. De zwaluw was een kei in vliegen, maar als het op graven aankwam, moest hij het onderspit delven. Hij brak steeds weer zijn bek en zijn vleugels. Spoedig zakte de score voor vliegen naar een vijf, graven bleef een één, en met de grootste moeite kon hij voor klimmen een drie halen. Soortgelijke ervaringen hadden de meeste andere dieren.

Het enige dier dat in een redelijke tijd de opleiding met succes afsloot, was een achterlijke worm, die voor elk vak een vijf of een zes wist te verkrijgen. Toch bleef de curriculumcommissie erg tevreden, want tenslotte liep iedereen alle vakken, en kon de school zich dus laten voorstaan op een brede opleiding.

U lacht natuurlijk bij zo'n verhaal, maar toch tekent het precies de situatie in het onderwijs. Het adagium is al eeuwenlang gelijkvormigheid: iedereen moet dezelfde dingen kennen en kunnen, en wat dat is bepalen de docenten. Deze hang naar gelijkvormigheid is ook doorgedrongen tot het universitaire onderwijs. In plaats van te zeggen tegen studenten "Denk voor jezelf" houden we hen onze eigen, vaak al verouderde, kennis voor en zeggen: "Dit is essentieel, dit is belangrijk, of zelfs: mijn zienswijze is de beste", in plaats van te zeggen: "Hier zijn enkele meningen en gedachten over dit onderwerp. Lees, luister, denk na, droom, en vind iets nieuws".

Dát is de opdracht van het universitaire onderwijs, en dít is dus onze eerste verantwoordelijkheid: de studenten leren 
zelfstandig en kritisch te denken. Is het immers niet zo dat de jongens en meisjes die we een diploma geven en dan uitwuiven, onze toekomstige maatschappelijke leiders zijn? Maar hoe kunnen ze die taak aan, als ze nooit hebben geoefend in het gebruik van het geweldige creatieve vermogen wan hun hersens? Deze gedachten leiden tot de volgende drie uitgangspunten bij het opzetten van een universitair curriculum.

Het eerste is dat de keuze van de vakken en van de eindtermen uitsluitend een zaak is van de universiteit. De aanwezigheid van universitaire beoepsopleidingen met extern vastgestelde eindtermen vind ik daarom iets bedenkelijks. Door zulke zaken dreigt de universiteit te verworden tot een soort super-Hво. Een universitaire beroepsopleiding is een contradictio in terminis.

Het tweede uitgangspunt is dat studenten vanaf het begin worden getraind in zelfwerkzaamheid en in het aankweken van een kritische houding tegenover de geboden stof. In dit verband citeer ik graag een uitspraak van Dijkstra, onder informatici wel bekend, die luidt: "studenten behoren te zijn als een wetsteen, waaraan docenten zich kunnen slijpen, en niet als een spons, die alles maar opzuigt".

Het derde uitgangspunt is dat studenten steeds tot aan de grenzen van hun kunnen worden belast: aan gemakkelijke studies heeft niemand wat.

Door Bollen [Bollen, 1988] is nog niet zolang geleden een inventarisatie gemaakt van het universitaire onderwijs in de bestuurlijke informatiekunde. Daaruit blijkt dat de curricula nogal verschillen en dat men ze nauwelijks kan vergelijken. Zoals hiervoor al is gesuggereerd, acht ik de wijze waarop een onderwerp wordt gedoceerd belangrijker dan de keuze van het onderwerp, en de wijze die ik voorsta is er een die wetenschappelijkheid uitstraalt en die studenten zelf vraagstukken laat ontdekken en aanpakken. In deze doelstelling past het 
Maastrichtse onderwijssysteem uitstekend. Het volgende citaat uit het amusante boekje 'Neo-Babelonia' van Gonick [Gonick, 1989] illustreert dit voortreffelijk:

\author{
"I hear and I forget \\ I see and I remember \\ I do and I understand."
}

Het huidige informatiekundige curriculum is een specialisatie binnen de afstudeerrichting Bedrijfseconomie gedurende de laatste tien blokken (een blok is éénzesde jaar). Met ingang van het studiejaar 1991/1992 is de toegemeten ruimte in het totale programma van Bedrijfseconomie gelijk aan dat van de andere kernvakken: Organisatie, Marketing, Financiering en Berichtgeving. Vanaf dat studiejaar is er dus een volledige informatiekundige specialisatie, beginnend na de propaedeuse.

Er zijn vergevorderde plannen om een meer kwantitatief gerichte economische studierichting op te zetten. Eén van de afstudeerrichtingen daarbinnen wordt een combinatie van informatiekunde en besliskunde.

Moet men in het onderwijs om diverse redenen nog wel eens water in de wijn doen, in het onderzoek is het mogelijk zich strikter te houden an het streven naar wetenschappelijke kwaliteit. Meer concreet bedoel ik hicrmee dat de sectie Informatie exactheid en precisie hoog in het vaandel heeft staan. Helaas staat het maken van deze opmerking binnen de informatiekunde niet gelijk aan het intrappen van een open deut.

Het grootste onderhanden onderzoeksproject is het SMARTIE-project, waarin onder andere het promorie-onderzoek van Van Diepen en Dijkhuis is ingebed. SMARTIE staat voor 'Specification, Modelling, Analysis and Refinement Techni- 
ques in Information systems Engineering". Dit project is een voortzetting van mijn promotie-onderzoek [Dietz, 1987]. Daarnaast participeert de sectie in twee landelijke projecten. Als afsluiting wil ik graag het recente initiatief tot samenwerking van de vier informaticagroepen binnen de Rijksuniversiteir Limburg vermelden. De initiatiefnemers zijn mijn collega's Crombag (Faculteit der Rechten), Hasman (Faculteit der Geneeskunde en Faculteit der Gezondheidswetenschappen), van den Herik (Faculteit der Algemene Wetenschappen) en ikzelf. In dit kader zijn twee nieuwe themagroepen van start gegaan, waarin elke faculteit is vertegenwoordigd. 


\section{Dankbetuiging}

Een benoeming tot hoogleraar is een erkenning van iemands waarde voor het wetenschappelijke onderwijs en onderzoek. Aan die waarde heeft in mijn geval de invloed van vele anderen in belangrijke mate bijgedragen. Enkelen wil ik graag met name noemen.

De eerste is professor Eykhoff (we hebben elkaar nooit bij de voornaam genoemd), hoogleraar in de meet- en regeltechniek aan de Technische Universiteit Eindhoven, die internationale naam heeft gemaakt door zijn werk op het gebied van systeemidentificatie en het schatten van systeemparameters, en die mijn afstudeerhooglleraar is gewreest.

De tweede is Ben Morselt, oud-directeur van het Rekencentrum van de Technische Universiteit Eindhoven, die het belang van een wetenschappelijke aanpak van alles wat men met computers deed, ook de administratieve automatisering dus, vanaf het begin heeft ingezien. Ben, ik kijk met plezier terug op de jaren in jouw 'Computing Laboratory'.

De volgende in de rij is Theo Bemelmans, mijn vorige baas en mijn tweede promotor. Ik bewaar de beste herinneringen, Theo, aan onze eerste schreden op het pad van de externe cursussen. Het belangrijkste echter dat ik van je heb geleerd is, denk ik, het verhogen van mijn ambitieniveau.

Hoewel ik er al lang van overtuigd was dat alles wat kan worden gezegd ook precies kan worden gezegd, heb ik van Kees van Hee, mijn eerste promotor, geleerd hóe je dat moet doen. Ik heb daarvan nog dagelijks profijt, Kees. 
Ik heb het geluk gehad aan deze universiteit te belanden temidden van coöperatieve en inspirerende mensen. Van zeer dichtbij zijn dat Peter Bollen en Ton van Reeken, de twee vaste medewerkers van onze sectie, Nancy Vandeberg, onze secretaresse, de promotie-onderzoekers Math van Diepen en Wilko Dijkhuiss, en tenslotte mijn beide in meer dan één opzicht bijzondere collega's Theo Mulder en Sjir Nijssen. Van degenen op iets grotere afstand wil ik graag Bram Beek en Dirk Tempelaar met name noemen.

Ik hoop met jullie nog veel samen te ondernemen.

Ik heb het geluk gehad dat ik uit ouders ben geboren van wie ik wat ik wilde en kon ook mocht. Bedankt, vader en moeder.

Ik heb het geluk gehad steeds mensen om me heen te weten die me hielpen uit mijn geestelijke putten te klauteren. Enkele van hen wil ik niet onvermeld laten. Allereerst is dat mijn moeder, die ik al noemde, maar die een dubbele vermelding best verdient. Vervolgens zijn dat Lia van Bergen en Wies Scheepstra, tevens de moeders van mijn kinderen. Bedankt daarvoor.

Lieve Wies, Claudine, Viviane, Sanne, Lisa en Tim. Ik snap best dat het soms well lijkt of ik een dubbele ploegendienst draai, en ik besef dat ik ook wel eens afwezig aanwezig ben. Bedankt dat jullie dat nemen.

It beb gezegd. 


\section{Literatuurlijst}

Austin, J.L., How to do things with words, Harvard University Press, Cambridge $M A, 1962$

Beer, S. Decision and Controh John Wiley \& Sons, 1966

Bemelmans, Th., Bedrijfskundig ontwerpen van bescuurlijke informatiesys. temen, in: Cornelis, P.A. en Oorschot, J.M. van, (red.), Ausomatisering wet een menselijk gezicht, Kluwer, Deventer, 1986

Bollen, PW.L., Bestuurlijke Informatiekunde aan universiteiten, in: Informatie, jaargang 30, 1988, p 640-650

Brussaard, B.K., Tas, P.A., Information and Organization Policies in Public Administration, in: Lavington, S.H. (ed.), Information Processing 80, NorthHilland Publ. Amsterdam, 1980

Bunge, M.A., Treatise on Basic Philosophy, vol. 3: Ontology I: the furniture of the world; vol. 4: Ontology II: a world of systems, D. Reidel Publishing Company, Dordrecht, Netherlands, 1979

Buscaglia, L., Love, Fawcert Crest Books, New York, 1972

Checkland, P., Systems Thinking, Systems Pracice, John Wiley \& Sons Lid., 1981

Chen, P.P., The Entity-Relationship-Model: Towards a Unified View of Data, in: ACM TODS, vol. 1, no. 1, 1976

wan Dale"s Groot Woordenboek der Nederlandse Taal, 1985

Date, C.J., An introduction to Database Systems, vol. I, 4th ed., Addison-Wesley Publ., 1986

Dietz. J.L.G., Modelleren en Specificeren wan Informatiesystemen, proefschrift Technische Universiteit Eindhoven, 1987

Dietz, J.L.G., A Communication Oriented Approach to Conceptual Modelling of Information Systems, in: Advanced Information Systems Exygineering, Lecture Notes in Compurer Science nr. 136, Springer-Verlag, 1990

Gall, J., Systemantics; How Systems Work And' Especially How They Fail, Fontana/Collins, Great Britain, 1979

Gonick, L., Neo-Babylonia, a serious study in contemporary confusion, L.J. Veen BV, Urecht, 1989 
Griethuysen, J.J. van, Jardine, D.A., Information Modelling with INFOMOD, wol. I, Philips Corporate Auromation-TMS, 1989

Koningsveld, H., Merrens, J. Communicatief en strategisch hamdelen, Coutinho, Muiderberg, 1986

Lundeberg, M., Goldkuhl, G., Nilsson, A., A Systematic Approach to Information Systems Development, in: Information Systems, vol. 4, 1979

Mulder, Th. J., Leiders en Informatiesystemen, Academic Service, 1990

Nielen, G.C., De bedoeling wan informatie woar mens en arganisatie, Samsom Uitgeverij, Alphen aan den Rijn, 1976

Nijssen, G.M. Grondslagen wan Bestuurlijke InformatieSystemen, Nijssen Adviesbureau voor Informatica BV, Slenaken, 1989

Open Universiteic, Gegevensmodellering en gegevensbanken, cursus wan de Open Universiteit, Heerlen, 1988

Peursen, C.A., van, Bertels, C.P., Nauta, D., Informatie: en interdisciplinaire studie, Aula-boeken, Utrecht, Het Spectrum, 1968

Ross, D.T., Plex 1: Sameness and the Need for Rigor, Softech, Inc, Waltham, $M A, 1975$

Searle, J.R., Speech Acts, Cambridge Uniwersity Press, Cambridge, 1969

Searle, J.R. Expression and Meaning, Cambridge University Press, Cambridge 1979

Shannon, C.E., The mathematical theory of communication, Bell Syst. Tech. f., voll. 27, pp 379-423 en pp 623-656

Sowa, J.F., Conceptual structures: Information Processing in Mind and Machine, Addison-Wesley Publ. Comp. 1984

Veld, J. in "t, Analyse van organisavieprablemen, Stenfert Kroese, Leiden, 1988

Ward, PT., Mellor, S.J., Structured Development for Real-Time Systems, Prentice-Hall Inc, 1985

Weinberg, G.M., An Introduction to General Systems Thinking, John Wiley \& Sons, 1975

Wittgenstein. L., Tratatus logico-philosophicus, uitgave Atheneum-Polak \& Van Gennep, Amsterdam, 1982

Winograd, T., Flores, F., Understanding Computers and Cognition: a New Foundation for Design, Addison. Wesley Publ. Comp., 1986

Yourdon E., Modem Structured Analysis, Prentice-Hall International Inc., 1989 
Omslagontwerp: Image Consult Wassenarar

Foto ornslag:

Steven Hunt U.S.A. 
Erratum bij 'Zo gezegd, zo gedaan' door dr. ir. J.L.G. Dietz

Op pagina 32 is bij vergissing een verkeerde figuur opgenomen. Figuur 3, die de cso's laat zien van twee meest eenvoudige netwerken, moet er als volgt uitzien:
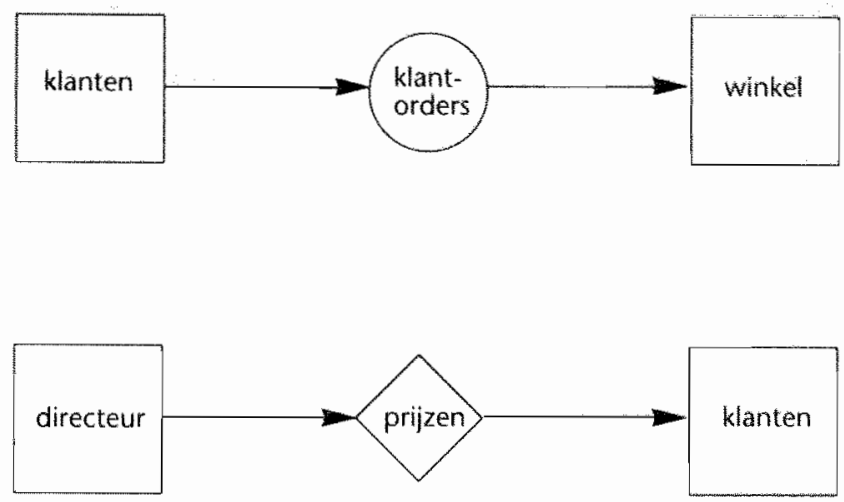

Figuur 3

\section{Aanvulling}

Op pagina 35 zijn aan de (informele) beschrijving van een mogelijke gedragsregel voor de actor 'Verkoop' van Bak \& Eet twee regels toegevoegd. De beschrijving ziet er nu als volgt uit:

\section{ALS}

er een klantorder voor 2 Innocentia's is en er zijn minstens 2 Innocentias in voorraad en de klant is bereid de verkoopsom te betalen DAN

haal 2 Innocentia's uit de voorraad en ruil die voor de verkoopsom; de voorraad Innocentia's is 2 lager; het kasgeld is de verkoopsom hoger. 